\title{
The Unfortunate Triumph of Form over Substance in Canadian Administrative Law
}

Paul Daly

Follow this and additional works at: http://digitalcommons.osgoode.yorku.ca/ohlj

Part of the Administrative Law Commons

Article

\section{Citation Information}

Daly, Paul. "The Unfortunate Triumph of Form over Substance in Canadian Administrative Law." Osgoode Hall Law Journal 50.2 (2012) : 317-357.

http://digitalcommons.osgoode.yorku.ca/ohlj/vol50/iss2/1 


\title{
The Unfortunate Triumph of Form over Substance in Canadian Administrative Law
}

\begin{abstract}
The standard of review analysis for judicial review of administrative action developed by the Supreme Court of Canada before Dunsmuir v New Brunswick had two important features. First, it provided a bulwark against interventionist judges, thereby protecting the autonomy of administrative decision makers and promoting deference. Second, it was substantive, rather than formal, and moved the focus of judicial review away from abstract concepts and towards the eccentricities of statutory schemes. However, in its more recent forays into the general principles of judicial review, the Court has threatened to reverse its deferential and substantive course by following a formalistic, categorical approach. In this article I describe the Court's efforts to reshape the law of judicial review of administrative action, critique these efforts as favouring a formalistic approach to judicial review, and suggest that in its haste to simplify the law of judicial review, the Court has jeopardized the due deference that should be accorded to administrative decision makers: It has erroneously favoured form over substance.
\end{abstract}

\section{Keywords}

Judicial review of administrative acts; Canada. Supreme Court; Canada 


\title{
The Unfortunate Triumph of Form over Substance in Canadian Administrative Law
}

\author{
PAUL DALY*
}

The standard of review analysis for judicial review of administrative action developed by the Supreme Court of Canada before Dunsmuir v New Brunswick had two important features. First, it provided a bulwark against interventionist judges, thereby protecting the autonomy of administrative decision makers and promoting deference. Second, it was substantive, rather than formal, and moved the focus of judicial review away from abstract concepts and towards the eccentricities of statutory schemes. However, in its more recent forays into the general principles of judicial review, the Court has threatened to reverse its deferential and substantive course by following a formalistic, categorical approach. In this article I describe the Court's efforts to reshape the law of judicial review of administrative action, critique these efforts as favouring a formalistic approach to judicial review, and suggest that in its haste to simplify the law of judicial review, the Court has jeopardized the due deference that should be accorded to administrative decision makers: It has erroneously favoured form over substance.

Les normes d'analyse élaborées par la Cour suprême du Canada avant Dunsmuir c New Brunswick pour la révision judicaire des mesures administratives comportaient deux caractéristiques essentielles. Premièrement, elles procuraient un rempart contre les juges interventionnistes, protégeant ainsi l'autonomie du décideur administratif et favorisant le devoir de réserve. Deuxièmement, elles donnaient préséance aux faits plutôt qu'aux principes et recentraient la révision judiciaire des concepts abstraits vers les particularités des lois. Cependant, dans ses plus récentes incursions dans les principes généraux de la révision judiciaire, la Cour menace d'inverser son mode d'action réservé et factuel pour le remplacer par une approche formaliste et catégorique. Dans cet article, je décris les efforts de la Cour visant à remanier le droit de la révision judiciaire des mesures administratives, je critique ces efforts qui favorisent selon moi une approche formaliste de la révision judiciaire et je suggère que dans sa hâte de simplifier le droit de la révision judiciaire, la Cour met en péril son devoir de réserve envers le législateur et favorise à tort la forme par rapport à la substance.

* Assistant Professor, Faculté de Droit, Université de Montréal. Thanks, with the usual disclaimer, to David Dyzenhaus, Matt Lewans and the anonymous reviewers for comments on a previous draft. 
II. THE CONFUSION OF DUNSMUIR: PRESUMPTIONS, CATEGORIES, AND FACTORS ……………....... 324

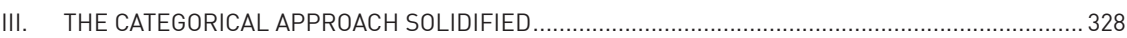

IV. ARE THE CATEGORIES SOUNDLY BASED?

A. Law, Fact, and Mixed Law and Fact …………….................................................... 331

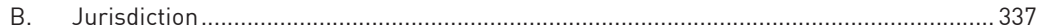

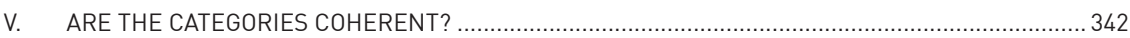

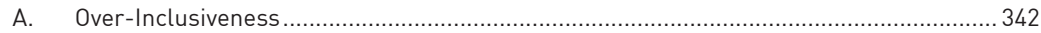

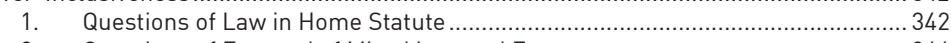

2. Questions of Fact and of Mixed Law and Fact.................................................... 344

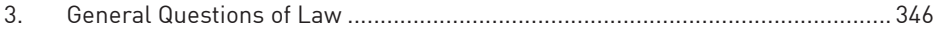

B. Under-Inclusiveness

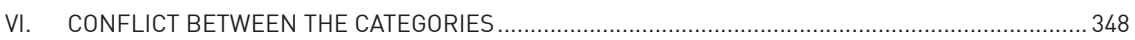

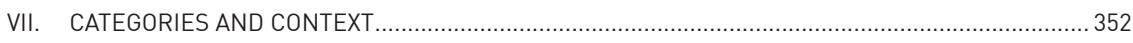

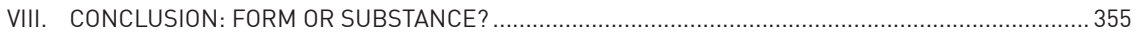

\section{INTRODUCTION: THE STANDARD OF REVIEW ANALYSIS}

ADMINISTRATIVE LAW CAN BE DIFFICULT to grasp. Judicial review, comprised in large part of abstract concepts, has a particularly slippery quality. At a high level of abstraction, however, it can be understood as the attempt by judges to allocate authority between the various organs of government found in the modern administrative state. Allocation requires choice, and choice requires a metric by which it can be made. When administrative lawyers talk of "error of law," "grounds of review," "jurisdictional error," and "standard of review analysis," they are talking about metrics, sometimes called doctrines. Underlying the choices and metricsand even choices of metrics_ - are public law values refracted through a prism of judicial attitudes, ideologies, and preferences. But choices and metrics may be limited by constitutional principles, such as an obligation to give effect to legislative intent, or provisions like section 96 of the Constitution Act, ${ }^{1}$ which has been interpreted as guaranteeing the availability of judicial review of administrative action. ${ }^{2}$

1. Constitution Act, 1867 (UK), 30 \& 31 Vict, c 3, s 96, reprinted in RSC 1985, App II, No

5. The provision mandates that the Governor General appoint the judges of the Superior,

District, and County Courts in each Province, excepting the Courts of Probate in Nova

Scotia and New Brunswick.

2. Crevierv Québec (Attorney General), [1981] 2 SCR 220, 127 DLR (3d) 1. 
A deferential attitude will manifest itself in doctrines that give a degree of latitude to administrative decision makers; but an attitude of judicial supremacy will be accompanied by doctrines that tend to constrain administrative decision makers. Once this is understood, one way of conceptualizing judicial review in very broad terms is to visualize judicial attitudes as something of a pendulum, capable of swinging from deference on the one side to judicial supremacy on the other. ${ }^{3}$ Note, though, that while one can accept the metaphor of the pendulum, one can also think that it ought to be frozen in a particular place. Certainly, I think that the pendulum should swing no longer and come to rest on the deferential side. ${ }^{4}$

In the early 1970s in the common law world, the pendulum had swung towards judicial supremacy. In its seminal decision in Anisminic, ${ }^{5}$ the House of Lords effectively jettisoned the possibility of intra-jurisdictional errors of law. Henceforth, any error of law committed by an administrative decision maker constituted a jurisdictional error which could be corrected on judicial review, ${ }^{6}$ even in the presence of a statutory provision purporting to exclude any review of the decision maker's decision. The old orthodoxy that errors of law could be made "within jurisdiction," and thus not be open to correction by a reviewing court, was no more. A move towards judicial supremacy had already been made by the resurrection of the doctrine of "error of law on the face of the record," whereby errors of law that appeared in the written disposition were open to correction, but Anisminic made the shift conclusive. In Metropolitan Life Insurance $v$ International Union of Operating Engineers, ${ }^{8}$ the Supreme Court of Canada followed suit without offering any analysis to support its decision to do so, even in the face of a statutory provision purporting to oust judicial review. In

3. For an earlier use of the metaphor, see Andrew J Roman, "The Pendulum Swings Back: Case Comment WW Lester (1978) Ltd v UA, Local 740" (1991) 48:1 Admin LR 274.

4. Paul Daly, "Deference on Questions of Law" (2011) 74:5 Mod L Rev 694; Paul Daly, $A$ Theory of Deference in Administrative Law (Cambridge: Cambridge University Press, 2012) [Daly, Theory of Deference].

5. Anisminic v Foreign Compensation Commission, [1969] 2 AC 147, 2 WLR 163 (HL) [Anisminic].

6. This is a general rule, subject to some limited exceptions. See In re Racal Communications Ltd, [1981] AC 374 at 383-384, (1980) 3 WLR 181; Rv Hull University Visitor, ex parte Page, [1993] AC 682 at 693-95, [1993] 1 All ER 97; Rv Monopolies and Mergers Commission, ex parte South Yorkshire Transport, [1993] 1 WLR 23 [Monopolies and Mergers Commission]. Monopolies and Mergers Commission may also be an authority for a limited exception, but its extent is very much a matter of uncertainty. See e.g. Paul Craig, Administrative Law $6^{\text {th }}$ ed (London: Sweet and Maxwell, 2008) at 467-70.

7. Rv Northumberland Compensation Appeal Tribunal, ex parte Shaw, [1952] 1 KB 338 at 352, 1 All ER 122.

8. [1970] SCR 425, 11 DLR (3d) 336 [Metropolitan]. 
Bell v Ontario (Human Rights Commission), ${ }^{9}$ the Court confirmed the existence of a distinction between jurisdictional errors and non-jurisdictional errors, with the former rendering any afflicted decision unlawful, even in situations where a final decision had not yet been taken.

There were two problems with this approach. First, it relied on formalistic distinctions between jurisdictional and non-jurisdictional errors, as well as distinctions between errors of law and other errors. Abstract categories were developed and applied without regard to the subject matter under review. No attention was paid to the intricacies of the underlying statutory scheme (including the characteristics of the decision maker and its decision-making process) that the legislature had established and that the administrative decision maker had interpreted:

Formalism is formal in that it requires judges to operate with categories and distinctions that determine results without the judges having to deploy the substantive arguments that underpin the categories and distinctions. Since those categories and distinctions must take on a life of their own in order to operate in this detached way, they are capable of determining results that contradict the very arguments for these categories and distinctions. ${ }^{10}$

Second, the approach was not deferential. It manifested an attitude of hostility towards administrative decision makers. One can speculate that common law judges remained in thrall to Dicey and considered themselves to be bulwarks against Leviathan, ${ }^{11}$ or that legal practice's constant search for the best answer to distinctively legal questions coloured the judicial attitude to reviewing errors of law. ${ }^{12}$

Whatever the reason, the Court's administrative law jurisprudence in the 1960 s and 1970s provoked some strong criticism, ${ }^{13}$ and the leading academics

9. [1971] SCR 756, 18 DLR (3d) 1 [Bell].

10. David Dyzenhaus, "Constituting the Rule of Law: Fundamental Values in Administrative Law” (2002) 27:2 Queen's LJ 445 at 450.

11. See Ian Holloway, "A Bona Fide Attempt': Chief Justice Sir Owen Dixon and the Policy of Deference to Administrative Expertise in the High Court of Australia" (2002) 54:2 Admin L Rev 687 at 698. This attitude is still prevalent. See e.g. Canada (Fisheries and Oceans) v David Suzuki Foundation, 2012 FCA 40 at paras 71-76 (available on CanLII).

12. See generally, Luc Tremblay, "La norme de retenue judiciaire et les 'erreurs de droit' en droit administratif: une erreur de droit? Au delà du fondationalisme et du scepticism" (1996) 56:2 R du B 141.

13. See e.g. HW Arthurs, "Rethinking Administrative Law: A Slightly Dicey Business" (1979) 17:1 Osgoode Hall LJ 1; PW Hogg, "The Jurisdictional Fact Doctrine in the Supreme Court of Canada: Bell v. Ontario Human Rights Commission" (1971) 9:1 Osgoode Hall LJ 203 [Hogg, "Jurisdictional Fact Doctrine"]; PW Hogg, "Judicial Review: How Much Do We Need?" 
of the day counselled a deferential approach. ${ }^{14}$ Although the Court's record was not roundly condemned, ${ }^{15}$ Justice Wilson, looking back, saw evidence of

a lack of sympathy for the proposition that if administrative tribunals are to function effectively and efficiently, then we must recognise (1) that their decisions are crafted by those with specialized knowledge of the subject matter before them; and (2) that there is value in limiting the extent to which their decisions may be frustrated through an expansive judicial review. ${ }^{16}$

Thus, by the end of the 1970s, there was some impetus for a deferential approach. The New Brunswick Liquor case $\mathrm{e}^{17}$ is "commonly considered the starting point for the acceptance of the notion of deference in Canadian administrative law and of its importance in framing the law of judicial review." ${ }^{18}$ In two important ways, Justice Dickson set Canadian law on a deferential course. First, he admonished reviewing courts "not [to] be alert to brand as jurisdictional, and therefore subject to broader curial review, that which may be doubtfully so." 19 Second, he held that an interpretation of law by an expert tribunal, made within its jurisdiction, could only be quashed by a court if the interpretation was patently unreasonable. ${ }^{20}$

The development of what came to be called the "standard of review" ${ }^{21}$ analysis gathered momentum in the $1980 \mathrm{~s}^{22}$ and $1990 \mathrm{~s} .{ }^{23}$ By the time of its decision in

(1974) 20:2 McGill LJ 157; Paul Weiler, “The 'Slippery Slope' of Judicial Intervention: The Supreme Court and Canadian Labour Relations 1950-1970” (1971) 9:1 Osgoode Hall LJ 1.

14. John Willis, "Canadian Administrative Law in Retrospect" (1974) 24:2 UTLJ 225 at 244-46; DJ Mullan, "The Federal Court Act: A Misguided Attempt at Administrative Law Reform?" (1973) 23:1 UTLJ 14 at 36-43.

15. PW Hogg, "The Supreme Court of Canada and Administrative Law, 1949-1971" (1973)

11:2 Osgoode Hall LJ 187; David Mullan, "The Jurisdictional Fact Doctrine in the Supreme Court of Canada - A Mitigating Plea” (1972) 10:2 Osgoode Hall LJ 440.

16. National Corn Growers Association v Canada (Import Tribunal), [1990] 2 SCR 1324 at para 8, 74 DLR (4th) 449. See also JM Evans, "Developments in Administrative Law: The 1984-85 Term” (1986) 8:1 Sup Ct L Rev 1 at 27-28.

17. Canadian Union of Public Employees, Local 963 v New Brunswick Liquor Corporation, [1979] 2 SCR 227, 25 NBR (2d) 327 [New Brunswick Liquor cited to SCR].

18. The Honourable Mr. Justice Louis LeBel, "Some Properly Deferential Thoughts on Deference" (2008) 21:1 Can J Admin L \& P 1 at 2.

19. New Brunswick Liquor, supra note 17 at 233.

20. Ibid at 237.

21. Dunsmuir v New Brunswick, 2008 SCC 9 at para 63, 1 SCR 190 [Dunsmuir].

22. Syndicat des employés de production du Québec et de l'Acadie v Canada Labour Relations Board and Canadian Broadcasting Corporation, [1984] 2 SCR 412, 14 DLR (4th) 457 [Canada Labour Relations Board]; Union des employés de service, local 298 v Bibeault, [1988] 2 SCR 1048, 95 NR 161 [Bibeault].

23. Pezim $v$ British Columbia (Superintendent of Brokers), [1994] 2 SCR 557, 114 DLR (4th) 
Pushpanathan ${ }^{24}$ the Court had refined this approach into a four-factor inquiry considering: (1) whether a privative clause protected the decision, or conversely, a right of appeal was provided for; (2) the expertise of the decision maker, relative to the reviewing court and relative to the decision under review; (3) the purpose of the decision maker as determined by a consideration of the parent statute; and (4) the nature of the decision, whether closer to law and more suited to judicial oversight, or closer to fact and thus demanding deference. Depending on the interplay of the four factors, one of three standards of review was to apply: correctness, which entitled the reviewing court to "undertake its own reasoning process to arrive at the result it judges correct"; ${ }^{25}$ reasonableness simpliciter, which required the reviewing court to test the impugned decision to ascertain whether it could withstand a "somewhat probing examination"; ${ }^{26}$ and patent unreasonableness, which required the reviewing court to affirm the decision unless it was "so patently unreasonable that [it] cannot be rationally supported by the relevant legislation and demands intervention by the court upon review." 27 The standards of review themselves formed something of a spectrum, ranging from correctness at the most interventionist point and patent unreasonableness at the most deferential.

The standard of review analysis had two important features. First, it provided something of a bulwark against interventionist judges. It is harder to go through a four-factor analysis and conclude that correctness is the appropriate standard of review than it is to classify a question as one of jurisdiction or law and thus apt for judicial intervention, effectively on a standard of review of correctness. Four steps are greater than one. I do not mean to suggest that the four-factor analysis presented an insurmountable hurdle. Doctrine can only do so much, and it is always open to subversion. ${ }^{28}$ But the standard of review analysis made it harder to

385; Canada (Director of Investigation and Research) $v$ Southam Inc, [1997] 1 SCR 748, 144 DLR (4th) 1 [Southam cited to SCR].

24. Pushpanathan $v$ Canada (Minister for Citizenship and Immigration), [1998] 1 SCR 982, 160 DLR (4th) 193 [Pushpanathan cited to SCR].

25. Law Society of New Brunswick $v$ Ryan, 2003 SCC 20 at para 50, 1 SCR 247, Iacobucci J.

26. Southam, supra note 23 at para 56 Iacobucci J.

27. New Brunswick Liquor, supra note 17 at 237, Dickson J.

28. See e.g. Grant Huscroft, "Judicial Review from CUPE to CUPE: Less is Not Always More" in Grant Huscroft \& Michael Taggart, eds, Inside and Outside Canadian Administrative Law: Essays in Honour of David Mullan (Toronto: University of Toronto Press, 2006) 296; Gabrielle Perrault, Le contrôle judiciaire des decisions de l'Administration: de l'erreur juridictionnelle à la norme de contrôle (Montréal: Wilson and Lafleur, 2002) at 100-04; Christopher Taylor, "Curial Deference and Judicial Review” (1991) 13:1 Advocates' Q 78; Mark Walters, "Jurisdiction, Functionalism, and 
justify intervention. It is not surprising that the New Brunswick Liquor decision has been described as having "marked the Court's acceptance of the legitimacy of the administrative state." 29

Second, the standard of review analysis was more substantive than it was formal. It was concerned with the intricacies of the statutory scheme rather than abstract concepts such as jurisdiction and error of law. ${ }^{30}$ In stark contrast to the formalistic distinctions that it replaced, the standard of review analysis required determinations of the appropriate intensity of judicial review to be "made on a case-by-case basis" ${ }^{31}$ in a manner "realistically cognizant of the institutional realities of the administrative state." ${ }^{32}$ In this sense, it was unrelentingly substantive:

Conceptual and abstract ways of thinking about law and legal problems have given way to an approach that pays more attention to the social, economic, and political contexts from which the issues arise, and to the likely consequences of resolving them one way rather than another, both for the immediately concerned litigants and for the wider public interests. ${ }^{33}$

Moreover, the "central inquiry" of the standard of review analysis was into legislative intent. ${ }^{34}$ On examining the substance of the statute establishing the

Constitutionalism in Canadian Administrative Law" in Christopher Forsyth et al, eds, Effective Judicial Review: A Cornerstone of Good Governance (Oxford: Oxford University Press, 2010) 300 at 307.

29. David Dyzenhaus \& Evan Fox-Decent, "Rethinking the Process-Substance Distinction: Baker v Canada" (2001) 51:3 UTLJ 193 at 200. However, "Judges remained at the apex of the interpretive hierarchy, with some accommodation made for the phenomenon of administrative decision making." Ibid at 203.

30. I do not claim that the standard of review analysis was entirely substantive. For example, the 'nature of the question' factor is just as formal as the concept of error of law; however, its relegation to a single factor rather than an organizing principle of judicial review pushed the standard of review analysis away from substance and towards form.

31. Ontario (Attorney General) v Ontario Public Service Employees Union (2000), 52 OR (3d) 77 at para 33, 195 DLR (4th) 376 (CA), Moldaver JA.

32. Robert Leckey, “Territoriality in Canadian Administrative Law" (2004) 54:3 UTLJ 327 at 362.

33. John M Evans \& Trevor Knight, "Cory on Administrative Law: A Contextual Study" in Patrick J Monahan \& Sandra A Forbes, eds, Peter Cory at the Supreme Court of Canada: 1989-1999 (Winnipeg: Canadian Legal History Project, 2001) 71 at 72.

34. Pushpanathan, supra note 24 at para 26, Bastarache J. This was largely, though not entirely, accurate. The "nature of the question" factor, for example, must be detached from legislative intent because there is no compelling basis from which to infer that legislators intend to delegate legal questions to courts or factual questions to administrative decision makers. Rather, for legitimacy, this factor must rely on a background assumption about the propriety of courts, as opposed to administrators, answering questions of law. 
decision maker and the provisions the decision maker had interpreted, a reviewing court could determine in a rough sense the intended relationship between the court and the decision maker. A link to legislative intent was capable of providing the standard of review analysis with a theoretical footing much firmer than any available to the formalistic distinctions relied upon previously. ${ }^{35}$

However, in its more recent forays into the general principles of judicial review, the Court has threatened to reverse its deferential and substantive course by substituting a formalistic, categorical approach for a contextual, case-by-case analysis. In this article, I will describe the Court's efforts to reshape the law of judicial review of administrative action; I will critique these efforts on the basis that the formal, categorical approach is not soundly based, is not coherent, and leads to conflict between the prescribed categories; I will argue that key questions about the new, unified standard of reasonableness have been inadequately answered; and I will suggest that in its haste to simplify the law of judicial review, the Court has jeopardized the due deference that should be accorded to administrative decision makers and has erroneously favoured form over substance. The problems with the new approach bode ill for the lower courts, lawyers, and litigants tasked with following it. For this reason, the problems ought to be highlighted, and the Court ought to be encouraged to change its course.

\section{THE CONFUSION OF DUNSMUIR: PRESUMPTIONS, CATEGORIES, AND FACTORS}

Theoretical consistency had, to some extent, been achieved by the early years of the twenty-first century. However, it came at the expense of practical understanding: It was said that the standard of review analysis provides "great flexibility but little real on-the-ground guidance, and offers too many standards of review." ${ }^{36}$ As a Federal Court judge complained:

As is becoming increasingly common in administrative law cases, a prodigious amount of time was spent by the parties, at both the hearing before me and in their written submissions, regarding the correct standard of review to be applied.

35. Daly, Theory of Deference, supra note 4, ch 2 .

36. Dusmuir, supra note 21 at para 43, Bastarache and LeBel JJ. For criticism from judges charged with applying the standard of review analysis, see e.g. Calgary Health Region $v$ United Nurses of Alberta, Local 95, 2005 ABQB 893 at para 20, 55 Alta LR (4th) 284; Currie v Canada (Customs and Revenue Agency), 2006 FCA 194 at paras 20-23, [2007] 1 FCR 471; Miller v Newfoundland (Workers' Compensation Commission) (1997) 154 Nfld and PEIR 52 (Nfld SC (TD)); Poulin c Centre hospitalier Anna Laberge, [2004] JQ No 4237 (CS). 
Although counsel did an admirable job of analysing the jurisprudence in order to delineate the fine and often obscure nuances between the concepts of patent unreasonableness and reasonableness simpliciter, it is obvious that what has developed in this field of law is an unwieldy framework which is unnecessarily complex and difficult to apply. ${ }^{37}$

For the Court, this was too high a price to pay, and it adopted the opportunity presented by Dunsmuir v New Brunswick to reshape Canadian administrative law. In the first paragraph of their majority reasons, Justices Bastarache and LeBel explained that the Court considered it necessary to develop solutions that could "provide real guidance for litigants, counsel, administrative decision makers or judicial review judges." ${ }^{38}$ In his concurring reasons, Justice Binnie identified "afoot in the legal profession a desire for clearer guidance than is provided by lists of principles, factors and spectrums." ${ }^{39}$ The standard of review analysis had drawbacks, chief among them being significant "predecision costs"; ${ }^{40}$ the reviewing court had to spend a significant amount of time focusing on matters that are, from a litigant's point of view, quite arcane. ${ }^{41}$

Accordingly, the Court implemented changes at both stages of the standard of review analysis. First, in determining the appropriate standard of review, the Court held that an "exhaustive review" of the standard of review analysis factors would not be "required in every case." ${ }^{2}$ In particular, where previous jurisprudence indicated the appropriate standard of review, a full analysis would be unnecessary since "the analysis required is already deemed to have been performed and need not be repeated." ${ }^{33}$ But also, the Court noted, it would not "be necessary to consider all of the factors, as some of them may be determinative in the application of the reasonableness standard in a specific case." ${ }^{44}$ Second, the Court held that the number of available standards should be reduced from three to two: "[T] he two variants of reasonableness review should be collapsed into a single form of 'reasonableness' review. The result is a system of judicial review comprising two standards—correctness and reasonableness." ${ }^{\prime 5}$ In what

37. Mountain Parks Watershed Assn v Chateau Lake Louise Corp, 2004 FC 1222 at para 11, 263 FTR 12, Rouleau J.

38. Dunsmuir, supra note 21 at para 1 .

39. Ibid at para 132 .

40. See generally Adrian Vermeule, Judging Under Uncertainty: An Institutional Theory of Legal Interpretation (Cambridge: Harvard University Press, 2006).

41. Dunsmuir, supra note 21 at para 133, Binnie J.

42. Ibid at para 57.

43. Ibid.

44. Ibid at para 64 .

45. Ibid at para 45. 
follows, I will concentrate on the Court's reshaping of the first stage, but afterwards I will return to the unified reasonableness standard.

Peppered throughout the Court's discussion in Dunsmuir of how reviewing courts should determine the appropriate standard of review are references to certain shortcuts or presumptions that should be borne in mind. For example, the presence of a privative clause would be a "strong indication of review pursuant to the reasonableness standard"; 46 it was also said that "[d] eference will usually result where a tribunal is interpreting its own statute or statutes closely connected to its function, with which it will have particular familiarity." ${ }^{47}$ On the correctness side of the ledger, the Court noted that previous jurisprudence had established that correctness would be the appropriate standard of review for several types of questions, namely constitutional questions, ${ }^{48}$ "true questions of jurisdiction," ${ }^{49}$ questions of general law, ${ }^{50}$ and those involving overlaps between different decision makers' jurisdictions. ${ }^{51}$ Nevertheless, the Court expressly retained the four factors that comprised the standard of review analysis ${ }^{52}$ and even applied them to the facts of Dunsmuir. ${ }^{53}$

That there was some conceptual confusion underlying the Court's analysis is suggested by its infelicitous observation that where a question of "fact, discretion or policy" is subject to review, "deference will usually apply automatically." ${ }^{4}$ It is worth pausing for a moment to consider the linguistic wonder that is 'the thing that usually happens automatically.' A sliding door that usually opens automatically is likely to lead to puzzled pedestrians at best and bruised noses at worst. A company that usually deposits paychecks automatically is unlikely to gain the trust of its employees. At least with respect to this category of decision, it is entirely unclear what the Court was trying to say.

This linguistic problem points to deeper problems with Dunsmuir. At the same time as it purported to establish presumptive categories to which either reasonableness or correctness would be appropriately applied, the Court maintained the four-factor standard of review analysis. It used the words "usually"

\footnotetext{
46. Ibid at para 52.

47. Ibid at para 54 .

48. Ibid at para 58 .

49. Ibid at para 59 .

50. Ibid at para 60 .

51. Ibid at para 61 .

52. Ibid at para 64 .

53. Ibid at paras 66-71.

54. Ibid at para 53.
} 
and "generally" on several occasions. ${ }^{55}$ It gave no guidance as to when the presumptions would be rebutted or displaced or what weight the presumptions should be given, which is problematic for reasons recently expressed by Justice Cromwell: "Creating a presumption without providing guidance on how one could tell whether it has been rebutted does not, in my respectful view, provide any assistance to reviewing courts." ${ }^{56}$ The Court also gave no guidance on the order in which a reviewing court should proceed. Should it consider the presumptions first and then the four factors? Or should it consider the four factors first and then the presumptions? On first sight, the second formulation might seem at odds with the Court's overall approach, but there is a logic to it. The four-factor standard of review analysis would be applied, but if it produced an anomalous result, reference to the presumptions would correct the anomaly. In some anomalous case, the four-factor analysis might suggest correctness, even in respect of a fact-laden decision, but the presumption that factual determinations attract deference would counsel reasonableness. ${ }^{57}$ This lack of clarity is troubling and indicative of a Court that may not truly know its own mind. ${ }^{58}$

55. Ibid at paras $51,53-54,57$

56. Alberta (Information and Privacy Commissioner) v Alberta Teachers' Association, 2011 SCC 61 at para 92, 3 SCR 654 [Alberta Teachers' Association].

57. See e.g. Dr Q v College of Physicians and Surgeons of British Columbia, 2003 SCC 19, 1 SCR 226. In the Court's view, three of the standard of review analysis factors pointed to correctness and only one towards deference. There, the standard of reasonableness simpliciter was available. Post-Dunsmuir, the four-factor analysis would at least point towards review on a correctness standard, but this may not be sufficient to rebut the presumption of deference.

58. A further lack of clarity is revealed by the ongoing uncertainty about Dunsmuir's applicability to non-adjudicative decision makers. See e.g. Globalive Wireless Management Corp v Public Mobile Inc, 2011 FCA 194 at para 35, 3 FCR 344 [Globalive]; Toussaint v Canada (Attorney General), 2011 FCA 213 at para 19, FCJ No 984 (QL); Georgia Strait Alliance v Canada (Minister of Fisheries and Oceans), 2012 FCA 40 at paras 83-100, FCJ No 157 (QL); Mamnuni $v$ Canada (Minister of Public Safety and Emergency Preparedness), 2011 FC 736 at para 33, FCJ No 1108 (QL). The Court has continued to assume the applicability of the unified approach established in Baker $v$ Canada (Minister of Citizenship and Immigration), [1999] 2 SCR 817, SCJ No 39 (QL) [Baker]. According to this approach, all decision makers exercising statutory powers are subject to the same general principles of judicial review. See e.g. Catalyst Paper Corpv North Cowichan (District), 2012 SCC 2 at paras 12-13, 1 SCR 5 [Catalyst]. I assume unity in what follows, with the caveat that the Court's future decisions will have to be watched and parsed closely to vindicate or defeat the accuracy of my assumption. 


\section{THE CATEGORICAL APPROACH SOLIDIFIED}

While the Court is still guilty of equivocating in its recent decisions,${ }^{59}$ it seems to have pinned its colours firmly to the mast of the categorical approach. In doing so, the Court has dashed the hopes of those who viewed Dunsmuir as offering "relatively modest adjustments" 60 or a lexical rather than conceptual contribution to the administrative law oeuvre. ${ }^{61}$ Justice Fish, writing for the majority in Smith $v$ Alliance Pipeline, explained the "analytical framework"62 established by Dunsmuir in the following terms. Correctness applies to: (1) constitutional issues; (2) questions of general law both of central importance to the legal system as a whole and outside the adjudicator's specialized area of expertise; (3) the drawing of jurisdictional lines between two or more competing specialized tribunals; and (4) true questions of jurisdiction or vires. Reasonableness is normally the governing standard where the question at issue: (1) relates to the interpretation of the tribunal's home statute or statutes closely connected to its function with which it will have particular familiarity; (2) raises issues of fact, discretion, or policy; or (3) involves inextricably intertwined legal and factual issues. ${ }^{63}$

Judging by the use of the word "normally" to describe the categories in respect of which reasonableness should be the "governing standard," 64 the Court is still equivocating somewhat. Indeed, the categories are also described as "nonexhaustive," 65 and the standard of review factors remain as "guideposts." 66

Further equivocal language can be found in respect of the categorical approach. Justice Fish commented in Alliance Pipeline that judges can "usefully begin their analysis" by ascertaining the appropriate category. He went on to

59. Smith v Alliance Pipeline, 2011 SCC 7, 1 SCR 160 [Alliance Pipeline]; Canada (Canadian

Human Rights Commission) v Canada (Attorney General), 2011 SCC 53, 3 SCR 471

[Canadian Human Rights Commission]; Nor-Man Regional Health Authority Inc v Manitoba Association of Health Care Professionals, 2011 SCC 59, 3 SCR 616 [Nor-Man]; Alberta

Teachers' Association, supra note 56.

60. Walters, supra note 28 at 308.

61. 'Aussi suis-je enclin à penser que Dunsmuir n'est qu'une péripétie de moindre importance, une contribution lexicale plutôt que conceptuelle au droit administratif canadien, et assez peu de choses à côté de l'arrêt SCFP." Yves-Marie Morissette, "Rétrospective et Prospective sur le Contentieux Administratif" (2008-2009) 39:1 RDUS 1 at 15.

62. Alliance Pipeline, supra note 59 at para 27. See similarly Alberta Teachers' Association, supra note 56.

63. Alliance Pipeline, ibid at para 26.

64. Nor-Man, supra note 59 at para 37.

65. Ibid at para 25.

66. Nor-Man, supra note 59 at para 41. 
note that "the first step will suffice ... in this case" ${ }^{67}$ —not, by implication, in all cases. But this equivocal language aside, the message of Alliance Pipeline and its confrères is clear: Reviewing courts should approach the task of judicial review by reference to a categorical approach. The first, and usually decisive, step will be to categorize the question at issue. Categorization, rather than a four-factor analysis, will determine the applicable standard of review. If it once were possible to say that Dunsmuir is "Pushpanathan in party dress," ${ }^{68}$ it is no longer the case. Indeed, Justice Fish's analysis in Alliance Pipeline focused on the categories into which the questions at issue fell, concluding first that "all fall within categories which according to Dunsmuir generally attract the standard of reasonableness," 69 and second that "[c]onversely, it is clear that this case does not fall within any of the categories which, under Dunsmuir, attract a standard of correctness." ${ }^{70}$ Moreover, the Court has purported to apply the categorical approach consistently in its recent decisions. For example, in Nor-Man Regional Health Authority Inc $v$ Manitoba Association of Health Care Professionals, ${ }^{71}$ the decision of a labour arbitrator was said to involve questions of fact, policy, and discretion for which a standard of review of reasonableness would be appropriate. In both Alberta (Information and Privacy Commissioner) v Alberta Teachers' Association ${ }^{72}$ and Canada (Canadian Human Rights Commission) v Canada (Attorney General), ${ }^{73}$ a reasonableness standard was also applied, ostensibly on the basis that the decisions at issue involved interpretations of the decision makers' home statutes. ${ }^{74}$

Categories can quite often be malleable. One striking difference between Dunsmuir and Alliance Pipeline is the breadth of the "general questions of law" category in the latter. In Dunsmuir, Justices Bastarache and LeBel described the category in the following terms:

[C] ourts must also continue to substitute their own view of the correct answer where the question at issue is one of general law "that is both of central importance to the legal system as a whole and outside the adjudicator's specialized area of expertise." Because of their impact on the administration of justice as a whole, such questions require uniform and consistent answers. Such was the case in Toronto (City) v. CUPE, which dealt with complex common law rules and conflicting

67. Alliance Pipeline, supra note 59 at para 25 [emphasis added].

68. Hudson Janisch, "Something Old, Something New" (2010) 23:3 Can J Admin L \& P 219.

69. Alliance Pipeline, supra note 59 at para 33.

70. Ibid at para 34 .

71. Nor-Man, supra note 59.

72. Supra note 56.

73. Supra note 59.

74. I use the words "purported" and "ostensibly" advisedly. 
jurisprudence on the doctrines of res judicata and abuse of process - issues that are at the heart of the administration of justice. ${ }^{75}$

To fit into this category, an issue must be (1) a question of general law; (2) of central importance to the legal system as a whole; (3) of such importance because of its impact on the administration of justice as a whole; and (4) outside the decision maker's expertise. ${ }^{76}$ In Alliance Pipeline, the third criterion was dropped. The category is now much broader. ${ }^{77}$ The examples given in Dunsmuir — res judicata and abuse of process-might be roughly described as procedural questions of wide importance, often for other areas of the legal system, on which administrators lack expertise relative to courts. ${ }^{78}$ Moreover, if the examples were intended as exemplars of the category, then the category was quite narrow. But by removing the requirement that the question raise issues relating to the administration of justice the Court has increased the scope of one of the correctness categories. The ease with which the Dunsmuir limitation was airbrushed out of judicial review doctrine is troubling.

Finally, it is striking that there is no similar equivocal language in respect of the correctness categories. This should be troubling for those who believe in deference. Some indeterminate factors might pull a decision from the reasonableness category into the correctness category, but there are no factors pulling in the opposite direction. In Dunsmuir and subsequently, the Court has mandated one-way traffic from reasonableness to correctness.

Having mapped out the terrain, I will argue in the following sections that the categories are unclear, that they are both over- and under-inclusive, and that they conflict. Confusion for lower-court judges, counsel, and litigants will be the unfortunate by-product of the formal approach preferred by the Court.

\section{ARE THE CATEGORIES SOUNDLY BASED?}

If it is thought desirable to follow a categorical approach, then the categories must have sound bases. As Justice Deschamps, the only member of the Court not to join Justice Fish's majority in Alliance Pipeline, rightly protested: "[T]he

75. Supra note 21 at para 60 [internal citation omitted].

76. See also the characterization of this category by the Québec Court of Appeal in Syndicat du personnel technique et professionnel de la Société des alcools du Québec (SPTP) c Société des alcools du Québec, 2011 QCCA 1642 at para 70 Bich JA [Syndicat du personnel technique].

77. See also Binnie J's wider-still conception of the category in his concurring reasons in Alberta Teachers' Association, supra note 56 at para 84.

78. See Gerald Heckman, "Nor-Man Regional Health Authority: Labour Arbitration, Questions of General Law and the Challenges of Legal Centrism" (2011) 35:1 Man LJ 63 at 72-73. 
development of any category of question that would tend to eliminate the need for a more fulsome analysis of the standard of review has to be grounded in a defensible rationale." ${ }^{\prime \prime 9}$ As I shall suggest, what are ostensibly neat distinctions between law, fact, and mixed law and fact turn out on proper examination neither to be neat nor based on a defensible rationale. ${ }^{80}$ Moreover, the reliance on a category of jurisdictional questions is extremely dubious. On the surface, the categories may look clear, but I will argue that any appearance of clarity is deceptive.

\section{A. LAW, FACT, AND MIXED LAW AND FACT ${ }^{81}$}

One should not be too quick to label a question one of "law." Proper characterization requires an appreciation of the nuances of the decision under review and the decision-making process that produced it. Consider the decision of the Court in Metropolitan Life Insurance $v$ International Union of Operating Engineers, ${ }^{82}$ the "high water mark of activist" judicial review of administrative action in Canada. ${ }^{83}$ At issue here was section 7(3) of the Ontario Labour Relations Act, ${ }^{84}$ which, inter alia, allowed the Labour Relations Board to certify a trade union as a bargaining agent if the Board were satisfied that more than fifty-five percent of the employees were "members of the trade union." The applicant company sought certiorari of a certification decision on the basis that its employees were not "members" of the respondent trade union within the meaning of the trade union's constitution. For its part, the Board had developed a policy whereby it assessed whether employees were members of a trade union by reference to a number of factors. The Court held that the Board had committed a reviewable error of law:

In proceeding in this manner the Board has failed to deal with the question remitted to it (i.e. whether the employees in question were members of the union at the relevant date) and instead has decided a question which was not remitted to it (i.e. whether in regard to those employees there has been fulfilment of the conditions stated above). ${ }^{85}$

79. Alliance Pipeline, supra note 59 at para 92.

80. I address the absence of a defensible rationale in more detail elsewhere. See Daly, Theory of Deference, supra note 4 , ch 6 at $220 \mathrm{ff}$.

81. This section draws heavily on and revises for a Canadian audience arguments I first formulated in Daly, "Deference on Questions of Law," supra note 4 at 701-06 and Daly, ibid at 238-43.

82. Metropolitan, supra note 8 .

83. JM Evans et al, Administrative Law: Cases, Text, and Materials 3d ed (Toronto: Emond Montgomery, 1989) at 565.

84. RSO 1960, с 202.

85. Metropolitan, supra note 8 at 435 . 
In other words, the Court characterized the phrase "members of the trade union" as meaning members within the definition of the trade union's constitution. It was, in the Court's view, a neat question of law: It appeared in a statutory provision (without further definition) and lent itself to an ordinary interpretation.

But the policy the Board had developed casts some doubt on whether the meaning of "members of the trade union" was such a neat question of law after all. As the Board explained in its decision, "what the Board is concerned with is whether the union accords all such employees full rights and privileges as members." ${ }^{86}$ It did not just rely on the formal definitions laid out in the trade union's constitution; rather, it conducted a context-sensitive inquiry. The inquiry was sensitive both to the circumstances of the group of employees and also to labour relations policy more generally, being particularly alert to the prospect that formal membership might not represent a trade union's actual level of support. In other words, the decision was one of mixed law and fact. Critically, there was no a priori reason for the Court to treat the phrase "members of the trade union" as presenting a question of law in some abstract sense. It was not a neat legal question since it required a sensitive evaluation of facts and policy. ${ }^{87}$ Rather than fitting neatly into a pre-determined category of "law," the question at issue in Metropolitan Life is better categorized as one of mixed law and fact. More than that, the example demonstrates the folly of relying solely on a categorical analysis. A reviewing court applying a standard of review analysis to the impugned certification decision would have had to assess the nature of the question, to be sure, but that would have been only one of the factors taken into account in calibrating the standard of review and would not have been decisive in and of itself.

It is undeniable that questions of law will sometimes be obviously so, and by their nature will be "easily separable from the undisputed facts of the case .... ." As I have suggested elsewhere, the choice of the relevant legal norm-statute, regulation, or guideline - and the decision to construe it can be considered questions of law, at least at a high level of generality. ${ }^{89}$ Selecting and developing the relevant legal definitions from the norm in question may also be questions of law. ${ }^{90}$ Having reflected on the example of the Metropolitan Life case, however, one should doubt that questions of

86. Ibid at 429 .

87. See e.g. Halifax (Regional Municipality) v Hoelke, 2011 NSCA 96 at paras 11-18, 308 NSR (2d) 277.

88. Pushpanathan, supra note 24 at para 47, Bastarache J.

89. Paul Daly, "Judicial Review of Errors of Law in Ireland" (2006) 41 Irish Jurist 60.

90. See e.g. Anisminic, supra note 5. 
law will regularly be obvious. Such considerations underpinned the warning given by Justice Abella in Lévis (City) v Fraternité des policiers de Lévis:" "[L]egal issues ought not to be declared readily extricable when they are legitimately and necessarily intertwined with the adjudicator's mandate and expertise." 92

Strategies can be employed to try to make questions of law obvious and apparent. For example, in Metropolitan Life, the Court could be said to have disposed of the narrow question of whether the board could take into account factors other than membership within the formal terms of the trade union's constitution. Here, to recall, the Court's answer was "no." This is a tantalizing avoidance strategy. Reformulated, the question is indeed narrower than the meaning of the phrase "members of the trade union." However attractive its siren song, the strategy is flawed because it does not account for the existence of "questions of degree." 93 Where a legal definition is in substance a question of degree, the factors legitimately taken into account may have a "quality of continuous variation" 94 or consist of "two or more relevant factors" 95 of variable weight. This was the case in respect of the phrase at issue in Metropolitan Life. Treating one factor as critical blinded the Court to the existence of a question of degree, pursuant to which it was up to the decision maker to decide whether factors additional to formal membership should be taken into account. While clever, the Court's avoidance strategy was improper.

A more honest strategy would be to identify questions of law by a process of elimination. One could say that there are three categories of question: law, fact (including inferences of fact), and mixed law and fact. ${ }^{96} \mathrm{~A}$ fact can be defined as "[an] assertion that a phenomenon has happened or is or will be happening independent of or anterior to any assertion as to its legal effect." ${ }^{\text {"97 }}$ As for inferences of fact, one recalls Jaffe's memorable phrase, "If the annual rate of depreciation of assets of a billion-dollar corporation is a 'fact', it is nevertheless a very different kind of fact from the bigness of Cyrano's nose." ${ }^{\prime 98}$ Once the facts have been

91. 2007 SCC 14,1 SCR 591.

92. Ibid at para 112.

93. WA Wilson, "Questions of Degree" (1969) 32:4 Mod L Rev 361.

94. Ibid at 365 .

95. Ibid at 368 .

96. A categorization relied upon by the Court in the context of appellate review. See Housen $v$ Nikolaisen, 2002 SCC 33, 2 SCR 235 at para 7. See also CT Emery \& B Smythe, "Error of Law in Administrative Law" (1984) 100 Law Q Rev 612 at 614-15.

97. Louis L Jaffe, "Judicial Review: Question of Law" (1955) 69:2 Harv L Rev 239 at 241.

98. Louis L Jaffe, "Judicial Review: Constitutional and Jurisdictional Fact" (1957) 70:6 Harv L Rev 953 at 979. 
ascertained, the decision maker must determine if they satisfy the relevant legal norm that "[e]very exercise of regulatory powers, even where there is no legal dispute, involves the application of law to facts, a process which requires the exercise of reasoning powers." 99 These questions of mixed law and fact constitute a grey area between questions of fact and questions of law. Following this strategy, a question could be said to be one of law if it were not one of fact or mixed law and fact.

This alternative approach has the merit of being honest, but it too is flawed because the distinction between law, fact, and mixed law and fact cannot withstand scrutiny. Consider the interaction between "law" and "fact," for example. While I do not doubt that there are questions that are clearly factual in nature, or that clearly involve an exercise of fact-finding powers or functions, the boundaries between fact and law are not so clear as to justify the creation of hermetically-sealed compartments. In determining the meaning of a statutory provision, assessments of the facts presented by a particular case will invariably influence the decision maker: "[I]l arrive ... que la compréhension initiale que l'on a d'une règle se nuance à la lumière de la preuve, ce qui ouvre la possibilité d'une interprétation nouvelle de la règle." $100 \mathrm{~A}$ good example is $R$ $v$ Skoke-Graham. ${ }^{101}$ At issue here was the predecessor to section 176(3) of the Criminal Code, pursuant to which it is an offence to "wilfully [do] anything that disturbs the order or solemnity" of a religious gathering. ${ }^{102}$ The appellants were convicted, having conducted a dignified protest against a Catholic Church policy that communion wafers should be distributed only to standing service-goers, not to those kneeling. Of interest for present purposes is the interpretive route that Chief Justice Dickson took in narrowing the scope of the provision such that the appellants' activity did not fall within the section:

If "disturb" ... is taken to encompass annoyance, anxiety or emotional upset, then "anything", no matter how trivial, which would lead to such annoyance, anxiety or emotional upset would be caught by the provision: a man might be convicted

99. Amnon Rubinstein, Jurisdiction and Illegality: A Study in Public Law (Oxford: Clarendon Press, 1965) at 16.

100. Fraternité des policiers et policières de la MRC des Collines-de-l'Outaouais c Collines-del'Outaouais (MRC des), 2010 QCCA 816 at para 27, 4 Admin LR (5th) 74, Morissette JA [Fraternité des policiers]. See also Stéphane Beaulac, Handbook on Statutory Interpretation: General Methodology, Canadian Charter and International Law (Markham: Lexis Nexis, 2008) at 14-15; JA Corry, "Administrative Law and the Interpretation of Statutes" (1936) 1 UTLJ 286 at 290-91; Hogg, supra note 13 at 163.

101. [1985] 1 SCR 106, SCJ No 6 (QL).

102. Criminal Code, RSC 1985, c C-46, s 176(3). 
under the section for failing to take his hat off in church, or failing to keep it on in synagogue. ${ }^{103}$

What is striking here is that an appreciation of the factual consequences of the interpretation of a statutory provision exerted a significant effect on the Court's determination of what was ostensibly a legal question. Even the distinction between "law" and "fact," which is so intuitively clear, seems to become blurred upon closer examination. ${ }^{104}$

Moreover, neither administrative decision makers nor courts employ the ostensibly neat distinction between law, fact, and mixed law and fact. At the very least, "the three 'stages' of the process do not in practice occur consecutively or even separately." 105 Indeed, given that courts do not consciously employ such a rigid reasoning process, "it would be strange if reviewing courts insisted on the division being rigidly maintained by administrative tribunals when it is not maintained by superior courts presided over by highly skilled lawyers." ${ }^{106}$ This should come as no surprise:

Perplexing problems may ... arise in analysing the nature of the process by which a tribunal determines whether a factual situation falls within or without the limits of a category or standard prescribed by a statute or other legal instrument. Every finding by a tribunal postulates a process of abstraction and inference, which may be conditioned solely by the adjudicator's practical experience and knowledge of affairs, or partly or wholly by his knowledge of legal principle. He hears evidence and, by satisfying himself as to its reliability, finds what were the "true" facts; it may then be necessary for him to draw a series of inferences from these primary findings in order to determine what were the material facts on which he has to base his decision; in order to draw certain of these inferences correctly he may need to apply his knowledge of legal rules. At what point does an inference drawn from facts become an inference of law? Is the application of a statutory norm to the material facts always to be classified as the determination of a question of law? And where in this spectrum lie questions of policy? ${ }^{107}$

103. Ibid at para 36 .

104. It could be that any application of the 'consequential analysis' tool of statutory interpretation would raise the same questions, but the problem is particularly pressing when a decision maker has been charged both with finding facts and interpreting legal provisions: It is hardly a stretch to posit that the meaning given to the statutory provisions will be influenced by the facts as found in the particular case, and the process of finding them.

105. Emery, supra note 96 at 615. See also Susan L Gratton, "Standing at the Divide: The Relationship Between Administrative Law and the Charter post-Multani" (2008) 53:3 McGill LJ 477 at 485-87.

106. Rubinstein, supra note 99 at 40.

107. SA De Smith, Judicial Review of Administrative Action, 5th ed by Lord Woolf \& Jeffrey Jowell (London, UK: Sweet and Maxwell, 1995) at 277. 
Given that confusion is inevitable and explanation is difficult, an analysis based on ostensibly neat categories of law, fact, and mixed law and fact risks undermining the autonomy of administrative decision makers. Without explaining its reasoning process, a court following a categorical approach can characterize a question as one of law, thereby requiring intrusive judicial review. Neat questions of law, however, do not arise with sufficient clarity to justify vesting such strong discretion in reviewing courts. ${ }^{108}$

Previously, the Court was sceptical about an approach that relied on distinctions between law, fact, and mixed law and fact, holding that " $[\mathrm{t}]$ here is no clear line to be drawn between questions of law and questions of fact, and, in any event, many determinations involve questions of mixed law and fact." 109 Justice Iacobucci put the point forcefully in Canada (Director of Investigation and Research, Competition Act) $v$ Southam Inc: 110 "[T] he distinction between law on the one hand and mixed law and fact on the other is difficult. On occasion, what appears to be mixed law and fact turns out to be law, or vice versa."111 No philosophical revolution has occurred in the years since those observations were made; the ostensibly neat distinctions remain nebulous. Worse, because of the vague nature of the distinctions, they are incapable of functioning as a means of allocating authority between administrative decision makers and reviewing courts. Indeed, they are an inappropriate means of doing so because they mask reviewing courts' true reasons for decision: "[D]istinctions between law, fact, and policy, acquire a concrete content only in relation to specific instances of administrative action, where they reflect the court's conclusions about the most appropriate division of responsibility between court and agency in all the circumstances." 122 Underpinning the categories developed by the Court are numerous assumptions about the appropriate allocation of interpretive responsibility. For example, there is the assumption that legal questions should be placed solely in the domain of courts. But the development and use of the categories masks these assumptions. That those assumptions may present a quiet departure from a deferential and substance-based approach should cause concern.

108. See also Heckman, supra note 78 at 77-82. Heckman criticizes the "legal centrism" of the category of questions of general law and suggests that its scope should be narrowed.

109. Pushpanathan, supra note 24 at para 37. See also Baker, supra note 58 at paras 53-55.

110. Southam, supra note 23.

111. Ibid at para 35 .

112. TRS Allan, "Constitutional Dialogue and the Justification of Judicial Review" (2003) 23:4 Oxford J Legal Stud 563 at 570. See also Mark Aronson, "Unreasonableness and Error of Law" (2001) 24 UNSWLJ 315; GL Peiris, "Jurisdictional Review and Judicial Policy: The Evolving Mosaic" (1987) 103 Law Q Rev 66 at 94-95. 


\section{B. JURISDICTION ${ }^{113}$}

As Justice Frankfurter once sagely observed, “Jurisdiction' competes with 'right' as one of the most deceptive of legal pitfalls." ${ }^{114}$ In this section, I equate jurisdiction with an administrative decision maker's power to take a decision. What I am most interested in are situations in which an administrative decision maker claims or relies on a power, the existence or legitimate exercise of which is subsequently contested before a reviewing court. A finding adverse to the administrative decision maker will lead to the conclusion that it committed a jurisdictional error by acting ultra vires its statutory authority.

The so-called ultra vires doctrine sought to anchor the justification for judicial review by anchoring it to legislative intent. ${ }^{115}$ The ultra vires doctrine is associated with what came to be the orthodox conception of jurisdiction in administrative law. ${ }^{116}$ The starting point is that the powers of administrative decision makers are necessarily limited. As Justice Beetz once explained, "any grant of jurisdiction will necessarily include limits to the jurisdiction granted." 117 Accordingly, if a statute provides that a decision maker can do $\mathrm{Y}$ only if $\mathrm{X}$ is present, then the presence of $\mathrm{X}$ is a pre-condition to the doing of $\mathrm{Y}$. To take a familiar example, a tribunal granted the power to make findings of discrimination in respect of the letting of self-contained dwelling units can only make a finding of discrimination $(\mathrm{Y})$ if a given premises is a self-contained dwelling unit $(\mathrm{X}) \cdot{ }^{118} \mathrm{Here}$, the existence of $\mathrm{X}$ is a pre-condition to the doing of Y. Moreover, it can be said that, by conditioning the doing of $Y$ on the existence of $\mathrm{X}$, the legislature intended to limit the jurisdiction of the administrative decision maker. By policing these limits, a reviewing court is simply giving effect to legislative intent:

[Jurisdictional facts] were to be distinguished from facts on which findings were conclusive only by the legislature's having marked them out as condition-forming facts; that is statutory language must show that these facts had actually to exist before the tribunal whose powers were being defined could have conditional jurisdiction. ${ }^{119}$

113. This section draws heavily on (and revises for a Canadian audience) arguments I first formulated in Daly, Theory of Deference, supra note 4 at 221-33.

114. Yonkers $v$ United States, 320 US 685 at 695, 64 S Ct 327 (1944).

115. See generally Tremblay, supra note 12 .

116. See generally Paul Craig, "Ultra Vires and the Foundations of Judicial Review" (1998) 57:1 Cambridge LJ 63.

117. Bibeault, supra note 22 at para 118.

118. See Bell, supra note 9. See also Rv London (City of) Rent Tribunal, Ex parte Honig, [1951] 1 KB 641, 1 All ER 195; $R$ (A) v Croydon London Borough Council, [2009] UKSC 8, 1 WLR 2557 [Croydon].

119. DM Gordon, "Conditional or Contingent Jurisdiction of Tribunals" (1960) 1:2 UBC L Rev 
On the orthodox view of the ultra vires doctrine, it falls to the reviewing court to determine whether the conditions for jurisdiction have been satisfied: "the fact must exist in the opinion of the reviewing court."120 Canadian courts have preferred to label this as the "preliminary question doctrine." ${ }^{21}$ They have good reason for doing so; at its outer limits, the preliminary question doctrine also applies to any questions of law said to have been interpreted by an administrative decision maker. ${ }^{122}$

Unfortunately, no formula has ever been devised for distinguishing $\mathrm{X}$ from $\mathrm{Y}$. S.A. De Smith's words ring as true today as they did decades ago: "No satisfactory test has ever been formulated for distinguishing findings which go to jurisdiction from findings which go to the merits." 123 The problem is that all statutory provisions can be cast in the following basic form: If X is present, then the decision maker shall or may $\mathrm{Y}$; if a majority of employees are members of a trade union, the Board may accredit it. In other words, $\mathrm{X}$ and $\mathrm{Y}$ are "inextricably interwoven." 124 As with the ostensibly neat distinctions between law, fact, and mixed law and fact, the effect of the inevitable uncertainty ${ }^{125}$ is to leave courts with strong discretion as to when to intervene: "The risk, of course, is that all a court need do to avoid the deferential standard of review ... is to classify a provision as one that goes to jurisdiction." 26 Their interventions would necessarily be based on considerations external to the preliminary question doctrine. As one commentator has observed, the preliminary question doctrine that the Court followed in the mid-twentieth century was "so malleable as to be capable of justifying the inclusion within its reach of any question of law or mixed law and fact that a tribunal was called upon to decide in the exercise of its mandate." 127 The Court's response was quite sensible, as the

185 at 197 [emphasis added].

120. Hogg, "Jurisdictional Fact Doctrine," supra note 13 at 210.

121. For a recent example, see Halifax (Regional Municipality) v Nova Scotia (Human Rights Commission), 2012 SCC 10 at para 34, 1 SCR 364 [Halifax].

122. BC Gould, "Anisminic and Jurisdictional Review" [1970] PL 358.

123. Supra note 107 at 255. See also Jaffe, supra note 97 at 959.

124. Paul Craig, "Jurisdiction, Judicial Control, and Agency Autonomy" in Ian Loveland, ed, A Special Relationship? American Influences on Public Law in the United Kingdom (Oxford: Clarendon Press, 1995) 173 at 177.

125. See Craig, Administrative Law, supra note 6 at 441. See similarly William Wade, "Constitutional and Administrative Aspects of the Anisminic Case" (1969) 85:338 Law Q Rev 198 at 210-11.

126. National Corn Growers Association v Canada (Import Tribunal), [1990] 2 SCR 1324 at para 23, SCJ no 110 (QL), Wilson J, concurring.

127. David Mullan, "The Supreme Court of Canada and Tribunals - Deference to the Administrative Process: A Recent Phenomenon or a Return to Basics?" (2001) 80 Can Bar Rev 399 at 423. See also JM Evans, "Developments in Administrative Law: The 1984-1985 
preliminary question doctrine was swallowed up by the standard of review analysis. Justice Beetz wrote in Union des employés de service, local $298 v$ Bibeault. ${ }^{128}$

The concept of the preliminary or collateral question diverts the courts from the real problem of judicial review: it substitutes the question "Is this a preliminary or collateral question to the exercise of the tribunal's power?" for the only question which should be asked, "Did the legislator intend the question to be within the jurisdiction conferred on the tribunal?" The chief problem in a case of judicial review is determining the jurisdiction of the tribunal whose decision is impugned. The courts, including this Court, have often remarked on the difficulty of the task. I doubt whether it is possible to state a simple and precise rule for identifying a question of jurisdiction, given the fluidity of the concept of jurisdiction and the many ways in which jurisdiction is conferred on administrative tribunals. ${ }^{129}$

Justice Beetz's retention of the language of jurisdiction may have preserved the attraction of the preliminary question doctrine for litigants and judges, but his development of the standard of review analysis undermined the doctrine. An entirely new approach was to be taken, pursuant to which a reviewing court would not parse a decision for jurisdictional errors or a statute for jurisdictional limitations. Rather than relying on the preliminary question doctrine to classify questions as jurisdictional and non-jurisdictional, reviewing courts would attempt to give effect to legislative intent. The development of a competing approach sounded the death knell for the preliminary question doctrine. The Court eventually said that the standard of review analysis "must be applied even to those provisions which appear to limit a tribunal's jurisdiction." ${ }^{130}$ In Crevier $v$ Québec (Attorney General), ${ }^{131}$ the Court had held that the Constitution requires that judicial review be available to keep decision makers within limits prescribed by legislatures. However, insofar as this could be described as jurisdictional review, it came to refer to questions which, according to the outcome of the standard of review analysis, were to be reviewed on a standard of review of correctness. Jurisdiction, then, became a label to describe the results of the standard of review analysis and not itself a key component in the analysis ${ }^{132}$ - a label, but one prone

Term" (1986) 8:1 Sup Ct L Rev 1 at 27-28.

128. Supra note 22. Cf. Beetz J's earlier position in Canada Labour Relations Board, supra note 22 at 441 .

129. Bibeault, ibid at paras 120-21.

130. Canadian Union of Public Employees, Local 301 v Montréal (City), [1997] 1 SCR 793 at para 44, SCJ No 39 (QL), L’Heureux-Dubé J.

131. Supra note 2. For criticism see HW Arthurs, "Protection against Judicial Review" (1983) 43:2 R du B 277.

132. See Pushpanathan, supra note 24 at para 30. See also The Honourable Michel Bastarache, 
to "analytical emptiness." 133 It certainly did not follow from the Court's logic in Crevier that the preliminary question doctrine, or anything like it, would have to be employed by reviewing courts, for all Crevier did was to "entrench ... some degree of review." 134

The multiplicity of difficulties attendant upon the use of the traditional conception of jurisdiction can be avoided by requiring a holistic inquiry into legislative intent. Such an inquiry focuses on the substance of the statutory provisions at issue. A judge following such an approach does not read a statute with a formal conception of jurisdictional questions in his or her mind. A reviewing court's decision to label a question as jurisdictional or non-jurisdictional should never fully answer the question of the appropriate degree of deference to accord because the concept of jurisdiction gives little or no guidance as to legislative intent. The very genius of the standard of review analysis was to recognize this flaw and avoid it. The concept of jurisdiction always remains relevant in the sense that decision makers cannot exercise unlimited power. ${ }^{135}$ But the boundaries of jurisdiction can be marked by the concept of unreasonableness; outside those boundaries, a decision could be struck down as unlawful, thereby securing some measure of judicial review.

In Public Service Alliance of Canada $v$ Canadian Federal Pilots Association, ${ }^{136}$ Justice Evans attempted to narrow the category of jurisdictional questions established by Dunsmuir almost out of existence. In light of the difficulties that

"Modernizing Judicial Review" (2009) 22 Can J Admin L \& Prac 227 at 231-34;

Huscroft, supra note 28 at 296-97. But cf. e.g. Chieu v Canada (Minister of Citizenship and Immigration), 2002 SCC 3 at para 24, 1 SCR 84, Iacobucci J. Iacobucci J evidences, perhaps, the lure of the traditional conception of jurisdiction: "Administrative bodies generally must be correct in determining the scope of their delegated mandate, given that they are entirely the creatures of statute." He perhaps also evidences the lure of the strict approach taken to review of jurisdictional determinations made by municipalities. See e.g. United Taxi Drivers' Fellowship of Southern Alberta v Calgary (City), 2004 SCC 19, 1 SCR 485.

133. Public Service Alliance of Canadav Canadian Federal Pilots Association, 2009 FCA 223 at para 40, [2010] 3 FCR 219, Evans JA [Federal Pilots Association]. See also Alberta Teachers' Association, supra note 56.

134. Julius H Grey, "Sections 96 to 100: A Defense" (1985) 1 Admin LJ 3 at 11. See also Metropolitan Toronto (Municipality) v Canadian National Railway Co, [1998] 4 FC 506 at para 11, FCJ No 1164 (QL). Strayer JA writes, "A reasonableness test, even on findings of jurisdictional fact, should provide adequate judicial control to avoid arbitrary or capricious determinations in support of the assertion of jurisdiction."

135. See Roncarelli v Duplessis, [1959] SCR 121, SCJ No 1 (QL).

136. Supra note 133. 
I have described with the formal conception of jurisdiction, I must agree in principle with Justice Evans's admonition that

it is too late in the development of administrative law in Canada for an applicant to invoke the ghost of jurisdiction past to inveigle the Court into reviewing for correctness a tribunal's interpretation of a provision in its enabling statute, without subjecting it to a standard of review analysis. ${ }^{137}$

I admire Justice Evans's evident distaste for the formal conception of jurisdiction. However, I must respectfully disagree with his conclusion that an applicant can establish that a decision maker has "exceeded its jurisdiction" only by demonstrating that the decision maker's interpretation "was unreasonable." 138 For good or ill, the Court expressly established a category of "true questions of jurisdiction or vires" in Dunsmuir. However, there are signs that Justice Evans's criticisms have had their intended effect. In Alberta Teachers' Association, ${ }^{139}$ Justice Rothstein, for the majority of the Court, indicated openness to the argument that the category of jurisdictional questions should be abolished entirely. ${ }^{140}$ Indeed, the Court has very recently gone so far as to overturn its decision in Bell v Ontario (Human Rights Commission), ${ }^{141}$ noting that the whole notion of "preliminary questions" central to the reasoning in Bell "has long since been abandoned."142 One hopes the Court will indeed take the step of abolishing the category of jurisdictional questions, but until it has done so, the formal conception of jurisdiction is not a ghost.

In summary, reliance on "law" and "jurisdiction" as the cornerstone of judicial review doctrine will cause Canada's administrative law superstructure to shift, bend, and creak. The categories are underpinned by hidden assumptions that do not support the deferential approach advocated by the Court. These assumptions are that reviewing courts should be able to intervene to correct jurisdictional errors and errors in answering general questions of law. However, no normative basis has been offered in Dunsmuir or other recent decisions in support of such an interventionist stance. ${ }^{143}$ Simply classifying questions as ones of law or jurisdiction is insufficient and masks rather than explains the content

137. Ibid at 52. See also Canada (Attorney General) v Public Service Alliance of Canada, 2011 FCA 257 at para 30, FCJ No 1325 (QL).

138. Federal Pilots Association, supra note 133 at para 50.

139. Alberta Teachers' Association, supra note 56.

140. Ibid at para 42.

141. Supra note 9.

142. Halifax, supra note 121.

143. The impossibility of providing such normative basis is discussed elsewhere. See Daly, Theory of Deference, supra note 4 , ch 6. 
of the concepts. Such shaky foundations do not augur well for an attempt to construct a relationship between courts and administrative decision makers that serves the needs of judicial review in the modern state.

\section{ARE THE CATEGORIES COHERENT?}

Quite apart from the difficulties identified in the previous section, the categories themselves are both over- and under-inclusive. I contend that this is a significant problem with the categorical approach. If a categorical approach is to be adopted, it is important that the categories are appropriately tailored. It is ever more important given the Court's equivocation as to what is required to move a particular decision out of one category and into another.

\section{A. OVER-INCLUSIVENESS}

\section{QUESTIONS OF LAW IN HOME STATUTE}

According deference to decision makers' interpretations of their home statutes carries significant appeal. Relative to a reviewing court staffed by generalists, a specialist administrative decision maker will often be better able to develop an interpretation of law that coheres with the principles and policies underpinning the statute.But to state as a rule that such interpretations should be reviewed on a reasonableness standard goes too far. ${ }^{144}$

There may be questions relating to the decision maker's home statute that are general in nature and thus not appropriate candidates for deference. As Justice Cromwell pointedly observed in Alberta Teachers' Association, ${ }^{145}$ there may be questions relating to the home statute which should be subject to review for correctness: " $[T]$ here are legal questions in 'home' statutes whose resolution the legislature did not intend to leave to the tribunal; indeed, it is hard to imagine where else the limits of a tribunal's delegated power are more likely to be set out." ${ }^{146}$

144. Indeed, it is not clear that one can take the Court literally on this point. See Alliance Pipeline, supra note 59 at para 85. As Deschamps J observed in Alliance Pipeline, in respect of the language used in Dunsmuir, "the language could be read broadly to capture any instance when the administrative decision-maker is interpreting its home statute; however, this interpretation does not sit well with any of the previous grounds that this Court has advanced for according deference." Binnie J has expressed similar concerns. See his concurring reasons in Alberta Teachers' Association, supra note 56 at paras 48, 81-83. Ultimately, he seemed to provoke the majority of the Court into accepting his position that deference to interpretations of home statutes should not be automatic.

145. Supra note 56.

146. Ibid at para 99. 
The approach of the Federal Court of Appeal in Canada (Attorney General) $v$ Mowat $^{147}$ is instructive (though not authoritative in its result, as the Court took a different view on appeal in Canada (Canadian Human Rights Commission) $v$ Canada (Attorney General)). ${ }^{148}$ Here, the question was whether the Canadian Human Rights Tribunal (the "Tribunal") had the power to award legal costs to a successful complainant under its authority to make awards in respect of "any expenses incurred by the victim as a result of the discriminatory practice." 149 The Tribunal concluded that it had such power. On review by the Federal Court, a standard of reasonableness was applied to the Tribunal's interpretation. However, the Federal Court of Appeal applied a standard of correctness. Justice LaydenStevenson held that the question at issue had no factual component and required no human rights expertise; rather, the Tribunal had to determine a "pure question of law, specifically, one that determines the bounds of its authority," in respect of which it had "no institutional or experiential advantage over the Court and [was] no better positioned than the Court." ${ }^{150}$ Although the Court took a different view of the appropriate standard of review in the circumstances, ${ }^{151}$ the general approach seems analytically sound and may well find adherents in future cases. ${ }^{152}$

Moreover, as Justice Deschamps pointed out in her concurring reasons in Alliance Pipeline, the decision maker might not necessarily have more expertise than the reviewing court relative to the question at issue:

Such a position is purely formalistic and loses sight of the rationale for according deference to an interpretation of the home statute that has developed in the jurisprudence including Dunsmuir, namely, that the legislature has manifested an intent to draw on the relative expertise or experience of the administrative body to resolve the interpretative issues before it. Such intent cannot simply be presumed from the creation of an administrative body by the legislature. Rather, courts should look to the jurisprudence or to the enabling statute to determine whether it is established in a satisfactory manner that the decision-maker actually has a particular familiarity - or put another way, particular expertise or experience relative to a court—with respect to interpreting its home statute. ${ }^{153}$

To develop a formal category of decisions to which reasonableness review applies is to disregard the substance of the individual decisions said to fall

147. 2009 FCA 309, [2010] 4 FCR 579 [Mowat].

148. Supra note 59.

149. Canadian Human Rights Act, RSC 1985, c H-6, ss 53(2)(c-d).

150. Mowat, supra note 147 at paras 43-44.

151. The court purported to apply the categorical approach in reaching this conclusion but in reality it relied on the standard of review analysis factors.

152. See e.g. Martinez-Caro v Canada (Citizenship and Immigration), 2011 FC 640, FCJ No 881 (QL).

153. Alliance Pipeline, supra note 59 at para 100. 
within the category. Moreover, one might observe, just because a decision maker has expertise, it does not follow that the expertise was actually applied to the decision in question; ${ }^{154}$ if it was, a more deferential standard of review will be appropriate. ${ }^{155} \mathrm{~A}$ reviewing court following a holistic approach, such as the standard of review analysis, can be alive to the possibility that expertise was not applied in a particular case. A reviewing court conducting a formalistic analysis of whether a decision falls into a particular category cannot be so alive. Justice Deschamps's concerns are well-founded.

\section{QUESTIONS OF FACT AND OF MIXED LAW AND FACT}

The same objections apply to the categories of questions of fact as well as mixed law and fact. It is overwhelmingly likely that reasonableness will be the appropriate standard of review of such decisions. The Court has been clear that factual determinations "command a high degree of deference."156 Indeed, traditionally "the courts have been very slow to accept as a matter of theory or policy that 'pure' errors of fact should be open to supervision." ${ }^{157}$ Administrators' closeness to and familiarity with factual matters within their bailiwick, allied to the fear of floodgates being burst open by waves of applications for review of contentious factual matters, probably explain this judicial reticence.

However, there may be factual determinations in respect of which a reviewing court would be as well or even better placed to give the best answer. A recent English example may be of assistance. In $R(A) v$ Croydon London Borough Council, ${ }^{158}$ the question was whether a local authority or a court should decide if an individual is a "child" for the purposes of section 20(1) of the Children Act 1989. ${ }^{159}$ This legislation confers numerous powers and imposes numerous duties on the courts and local authorities, contingent upon a finding that a person is a child. But the question of who is a "child" can be difficult to answer, particularly

154. See generally Lorne Sossin, "Empty Ritual, Mechanical Exercise or the Discipline of Difference? Revisiting the Standard of Review in Administrative Law" (2003) 27:4 Advocates' Q 478.

155. This is analogous to cases in which a decision maker's expertise is simply not relevant to a question it has attempted to answer. See e.g. Elgie v Alberta (Workers' Compensation, Appeals Commission), 2009 ABCA 277 at paras 32, 34, 311 DLR (4th) 503.

156. Canada (Citizenship and Immigration) v Khosa, 2009 SCC 12 at para 46, [2009] 1 SCR 339 [Khosa].

157. Christopher Forsyth \& Emma Dring, "The Final Frontier: The Emergence of Material Error of Fact as a Ground of Judicial Review" in Christopher Forsyth et al, eds, Effective Judicial Review: A Cornerstone of Good Governance (Oxford: Oxford University Press, 2010) 245 at 249.

158. Supra note 118.

159. (UK), 1989, с 41. 
in situations where the circumstances of an individual's birth have, for whatever reason, not been adequately documented. Section 20(1) obliges local authorities to provide accommodation for "any child in need within their area." 160 The local authority argued that the judgment of "need" must be an evaluative one and that an appropriate judgment could be made only by the local authority's staff, who possessed the relevant expertise. On this view, judicial review would be available, but the primary decision would be for the local authority. This argument did not find favour with Lady Hale, who instead drew a distinction between the objective factual question of "what is a child" and the evaluative factual question of "what is a child in need":

The arguments advanced by [the local authority] might have to provide an answer in cases where Parliament has not made its intentions plain. But in this case it appears to me that Parliament has done just that. In section 20(1) a clear distinction is drawn between the question whether there is a "child in need within their area" and the question whether it appears to the local authority that the child requires accommodation for one of the listed reasons. In section 17(10) a clear distinction is drawn between whether the person is a "child" and whether that child is to be "taken to be" in need within the meaning of the Act. "Taken to be" imports an element of judgment ... which Parliament may well have intended to be left to the local authority rather than the courts. ${ }^{161}$

It is striking that Lady Hale was so exercised by the intricacies of the statutory regime. She parsed the statute in a search for the intention of the legislature, not for jurisdictional limitations. Equally striking was her subsequent insistence that questions of relative expertise were relevant to determining legislative intent. Lady Hale acknowledged that the question of whether an individual was a "child" or not might often be a difficult one, but held that the courts are sufficiently adept at answering such questions. What is true of determining an individual's age "is true of many questions of fact which regularly come before the courts. That does not prevent them from being questions for the courts rather than for other kinds of decision makers." 162 Deference to administrative decision makers on questions of fact will not, on Lady Hale's approach, automatically be appropriate. An analysis of the statutory scheme and the relative expertise of the bodies involved will be necessary before a conclusion can be reached on the allocation of authority.

160. Ibid, s 20(1).

161. Croydon, supra note 118 at 28.

162. Ibid at 27. 
A conclusion like the one reached by the UK Supreme Court in Croydon may be rare, but in principle, it can occur. If, in principle, such an outcome can occur in respect of factual determinations, where deference is most likely to be appropriate, then it is a fortiori capable of occurring in respect of determinations of mixed fact and law. In short, a standard of review of reasonableness will not always be appropriate.

\section{GENERAL QUESTIONS OF LAW}

On the correctness side of the post-Dunsmuir ledger, the categories are also overinclusive. In respect of general questions of law, a decision maker may be more expert than a reviewing court - especially given the expansion of that category in Alliance Pipeline ${ }^{163}$ For example, the question at issue in Metropolitan Lifewhat constituted membership of a trade union-could easily be said to be a question of general law that is of central importance to the legal system. ${ }^{164}$ The phrase "members of a trade union" appears in federal legislation and in numerous provincial statutes. ${ }^{165}$

However, a large part of the reason that Metropolitan Life is now treated with such disdain ${ }^{166}$ is that this is precisely the sort of question on which a labour relations board could easily be said to have more expertise than a generalist reviewing court. ${ }^{167}$ First, a labour relations board will address such questions on a regular basis and, being staffed by experts in the field, will have an advantage relative to a court in determining which approach to take to the question of membership to best achieve its statutory objectives. Second, different labour relations boards can justifiably take different approaches to the question of membership; it is not self-evident that the same conditions will be present in both Alberta and Newfoundland, and different policies may be required to respond to the complexities present in different jurisdictions. Third, as practices in the labour relations community change, it may be prudent for labour relations boards to change their policies, perhaps with input from employer and employee representatives, a possibility foreclosed by national resolution of the question of membership.

163. See text accompanying supra note 74 .

164. Equally, of course, it could be said to be an interpretation of a home statute; as I will demonstrate below, there will often be such conflict between the categories.

165. See e.g. Trade Unions Act, RSC 1985, c T-14, ss 4(1)(a), 6; Labour Relations Act, RSNL 1990, c L-1, ss 70(7)(b), 70(8), 128(1); Labour Relations Code, RSA 2000, c L-1, ss 29(1), 85(a), 92(3), 151(d), 151(e), 202(1), 203.

166. See text accompanying supra note 81.

167. Paul C Weiler, "The 'Slippery Slope' of Judicial Intervention: The Supreme Court and Canadian Labour Relations 1950-1970” (1971) 9:1 Osgoode Hall LJ 1 at 2-4. 
These considerations might be unique to the labour relations context, but similar ones can be expected to arise in other areas. ${ }^{168}$ If the approach taken in Metropolitan Life is indeed now considered to be bad law, if not "pure nonsense," 169 it is troubling that the Court's categorization efforts threaten to usher it back into Canadian judicial review doctrine. Some of these concerns are assuaged by the attitude that the Court took in Nor-Man Regional Health Authority Inc v Manitoba Association of Health Care Professionals ${ }^{170}$ to the application of the common law concept of estoppel by a labour arbitrator. In this case, the Court held that a reasonableness standard was appropriate. However, Justice Fish's reasoning was heavily contingent on the characteristics of the labour arbitrator, ${ }^{171}$ which opens up the unhappy prospect that the "pure nonsense" represented by Metropolitan Life might be acceptable outside the labour relations context.

\section{JURISDICTIONAL QUESTIONS}

The scope of the category of true questions of jurisdiction, or vires, is uncertain. In Dunsmuir, Justices Bastarache and LeBel insisted-repeating Chief Justice Dickson's admonition in New Brunswick Liquor-that "[ $\mathrm{t}]$ hese questions will be narrow ... reviewing judges must not brand as jurisdictional issues that are doubtfully so." ${ }^{172}$ In Alberta Teachers' Association ${ }^{173}$ Justice Rothstein suggested that, at best, such questions would be "exceptional." 174 Nevertheless, even a narrow category of "true" questions has the potential to include too many administrative decisions.

A decision maker's expertise may often be relevant in answering jurisdictional questions. It is likely that a decision maker will be more familiar than a reviewing court with the contours of the relevant regulatory domain and the areas in which the decision maker could usefully and appropriately exercise its powers. ${ }^{175}$ Thus, it was shrewd of Justice Abella to advise in Council of Canadians with Disabilities $v$ VIA Rail Canada" 176 that courts should "refrain from overlooking the expertise

168. See e.g. New Brunswick (Human Rights Commission) v Potash Corp of Saskatchewan Inc, 2006 NBCA 74 at para 61, 271 DLR (4th) 483.

169. Supra note 167 at 32 .

170. Supra note 59.

171. Ibid at paras 45-53.

172. Dunsmuir, supra note 21 at para 59. See similarly Khosa, supra note 156 at para 45.

173. Alberta Teachers' Association, supra note 56.

174. Ibid at para 39.

175. See e.g. Quincy M Crawford "Chevron Deference to Agency Interpretations that Delimit the Scope of the Agency's Jurisdiction” (1994) 61:3 U Chicago L Rev 957 at 981.

176. 2007 SCC 15, 1 SCR 650. 
a tribunal may bring to the exercise of interpreting its enabling legislation and defining the scope of its statutory authority." 177

Such a nuanced method is ruled out by the categorical approach. Again, one of the categories turns out to be over-inclusive. However, at least here the bell may be tolling for the category of true questions of jurisdiction or vires, judging by the Court's treatment of it in Alberta Teachers' Association. ${ }^{178}$ If this category is indeed jettisoned, its over-inclusiveness will go with it.

\section{B. UNDER-INCLUSIVENESS}

The categories are also under-inclusive in important respects. Deference for a wider range of administrative decisions than that envisaged by the categories is appropriate. Most obviously, an administrative decision maker may be better able to resolve questions of general law and jurisdictional questions than a reviewing court would be. This implies that limiting the categories of decision to which deference should be accorded to factual questions, questions of mixed fact and law, and interpretations of a decision maker's home statute is inappropriate. Similarly, deference may also be appropriate regarding questions that appear to be jurisdictional in nature. Simply put, the categories are under-inclusive because they do not capture the full range of decisions on which a standard of review of reasonableness would be appropriate.

\section{CONFLICT BETWEEN THE CATEGORIES ${ }^{179}$}

It follows from the argument up to this point that there is a serious potential for conflict between the categories. The Court's recent decisions provide ample demonstration that this potential for conflict has been realized.

Canada (Canadian Human Rights Commission) $v$ Canada (Attorney General), ${ }^{180}$ discussed above, provides a first example. Recall that the Federal Court of Appeal held that the Canadian Human Rights Tribunal was not entitled to deference even though it was interpreting a provision in its home statute, because the question of whether the Tribunal had the power to award costs was a question of general law. But following the categorical approach, it is difficult to

177. Ibid at para 89 [emphasis added].

178. Alberta Teachers' Association, supra note 56.

179. The argument in this section draws in part on the more complete descriptions of the cases provided in Paul Daly, "Dunsmuir's Flaws Exposed: Recent Decisions on Standard of Review" (2012) 58:2 McGill LJ 1.

180. Supra note 59. 
see how the question at issue should be categorized. On the one hand, it clearly relates to an interpretation of the decision maker's home statute. But on the other hand, it could be categorized as a question of general law: Many decision makers would be interested in the scope of their authority to award costs to successful claimants or participants. ${ }^{181}$

At the Supreme Court of Canada, the conflict between the categories was ultimately resolved by reference to factors external to the categories. For the Court, Justices LeBel and Cromwell held that determining whether legal costs could be awarded in such circumstances fell "within the core function and expertise" of the Tribunal ${ }^{182}$ because it was "inextricably intertwined with the Tribunal's mandate and expertise to make factual findings relating to discrimination." 183 They noted that the Tribunal was in a good position to assess the need to award costs in particular cases that came before it. ${ }^{184}$ Finally, they emphasized that the question required a fact-sensitive inquiry. ${ }^{185}$ In other words, to determine the appropriate standard of review, Justices LeBel and Cromwell employed factors from the standard of review analysis: expertise, the factual nature of the question, and the purpose of the statutory provision in question. ${ }^{186}$

A second example is Nor-Man Regional Health Authority Inc v Manitoba Association of Health Care Professionals. ${ }^{187}$ At issue here was a labour arbitrator's interpretation of a collective agreement. The union had abided for many years by the employer's interpretation of a provision relating to eligibility for additional paid leave but eventually grieved the interpretation. The arbitrator decided that the employer's interpretation was incorrect, but that the union, by virtue of its many years of acquiescence, was estopped from challenging it. The courts below were split on the appropriate standard of review. On the one hand, as the Manitoba Court of Appeal held, estoppel is a common law principle. It is a question of general law beyond the expertise of labour arbitrators and appropriately subject to judicial oversight on a correctness standard. ${ }^{188}$ On the other hand, applying a concept such as estoppel in the particular context of labour relations unavoidably

181. See e.g. Kelly v Alberta (Energy Resources Conservation Board), 2012 ABCA 19, Alta LR (5th) 391.

182. Canadian Human Rights Commission, supra note 59 at para 25.

183. Ibid.

184. Ibid.

185. Ibid at para 26.

186. See similarly Canada (Attorney General) v Tipple, 2011 FC 762 at paras 27-35, 91 CCEL (3d) 132.

187. Supra note 59.

188. Manitoba Association of Health Care Professionals v Nor-Man Regional Health Authority Inc, 2010 MBCA 55 at para 46, 255 Man R (2d) 93. 
raises interlocking issues of fact and policy, features that support the decision of the judge at first instance to apply a standard of review of reasonableness. ${ }^{189}$

The Court was unanimous in concluding that a standard of reasonableness ought to apply. The unique position of labour arbitrators was central to the conclusion. Justice Fish noted that labour arbitrators operate under broad statutory and contractual mandates. This breadth is necessary to allow them to fulfill the difficult role of mediating between management and labour in order to foster industrial peace. The generosity of their mandates is also appropriate given their expertise in the field of labour relations. Finally, Justice Fish emphasized that labour arbitrators are uniquely well positioned to respond to the exigencies of the employer-employee relationship. ${ }^{190}$ Expertise and statutory purposefactors drawn from the standard of review analysis - were crucial to Justice Fish's conclusion that a standard of review of reasonableness should be applied. Two other factors external to the categorical approach were also relevant: the extent of the labour arbitrator's statutory mandate ${ }^{191}$ and the complexity of the problem underlying the decision in issue.

In Alberta Teachers' Association, ${ }^{192}$ the issue was whether the decision maker had exercised a power before the expiry of a ninety-day deadline established by its home statute. Both of the lower courts accepted that this was a jurisdictional question to which the decision maker was obliged to give a correct answer. ${ }^{193}$ The Supreme Court of Canada applied a standard of review of reasonableness on the basis that the decision maker was interpreting its home statute and thus entitled to deference.

For the majority of the Court, Justice Rothstein held that the decision under review did not fall into any of the correctness categories. ${ }^{194}$ The appropriate category was that of a decision interpreting the decision maker's home statute,

189. Manitoba Association of Health Care Professionals v Nor-Man Regional Health Authority Inc, 2009 MBQB 213 at para 11-13, 243 Man R (2d) 281. See further Heckman, supra note 78 at 73-77.

190. Nor-Man, supra note 59 at $42-53$.

191. See also Telfer $v$ Canada (Revenue Agency), 2009 FCA 23 at para 40, 4 CTC 123.

192. Alberta Teachers' Association, supra note 56.

193. [2008] 21 Alta LR (5th) 24, 1 Admin LR (5th) 85; 2010 ABCA 26 at paras 37-40, 316 DLR (4th) 117 (affd).

194. Recall that Rothstein J expressed significant skepticism about the category of "true questions of jurisdiction or vires," announcing himself unable to provide a definition. See text accompanying supra notes 137-140. Tellingly, he did not explain why the question at issue was not a jurisdictional question. Thus only the artful avoidance of a conflict between classifying the relevant issue as a jurisdictional question or an interpretation of a home statute prevented the flaws of the categorical approach from being even more cruelly exposed. 
which attracted a reasonableness standard. However, in determining that the question was not one of general law, Justice Rothstein noted that the decision was "squarely" within the "specialized expertise" of the decision maker. ${ }^{195} \mathrm{He}$ also identified as important the decision maker's "significant familiarity" with an issue "specific" to its home statute. ${ }^{196}$ Finally, he described the decision maker's role as centering upon balancing the rights of individuals to privacy against organizations' needs to disclose information in certain circumstances, necessitating a complex process of keeping the interests of the parties in alignment. ${ }^{197}$ The decision on the appropriate standard of review was saturated with references to the standard of review analysis factors.

It is clear then that in its recent decisions on standard of review the Court has relied partly on the standard of review analysis factors ${ }^{198}$ and partly on other factors such as the breadth of the decision maker's mandate and the complexity of the subject matter of the decision. Provincial courts are not immune. ${ }^{199}$ Using the standard of review analysis in this way might cohere with the Court's approach in Dunsmuir, which marginalized the standard of review analysis but did not push it entirely out of the judicial review framework. Thus, despite having been marginalized, the standard of review analysis could yet play an important role in ensuring that decisions are assigned to the appropriate categories. Of course, if the standard of review analysis were to play such a role, the utility of the categorical approach would be called into serious question since the standard of review analysis would be doing the heavy lifting by placing the decisions in the appropriate silo. Why bother at all, then, with a formal approach that lacks internal coherence and is not capable of resolving difficult cases? That the Court has not yet fully thought through its new approach is surely cause for lament. For now, the obvious potential for conflict between the categories suggests that, far from laying confusion to rest, the Court has merely relocated it. Any suggestion that categorization will lead to a more straightforward body of judicial review law looks dubious at best and badly mistaken at worst.

195. Alberta Teachers' Association, supra note 56 at para 32.

196. Ibid.

197. Ibid.

198. For some accurate prognostication, see Ron Goltz, "Patent Unreasonableness is Dead. And We Have Killed It.' A Critique of the Supreme Court of Canada's Decision in Dunsmuir" (2008) 46:1 Alta L Rev 253.

199. See e.g. Mellor v Saskatchewan (Workers' Compensation Board), 2012 SKCA 10 at para 20, 385 Sask R 210. The court relied heavily on expertise. See also Syndicat du personnel technique, supra note 76 at paras $71-72$. The court relied on complexity, purpose of the statutory provisions, and expertise. 


\section{VII.CATEGORIES AND CONTEXT}

An important point about the new standard of review of reasonableness follows from the foregoing discussion. Given that the aim of Dunsmuir and its confrères seems to be to replace the standard of review analysis with a new categorical analysis, it is worth assessing the implications of this change for the second stage of the standard of review analysis. As I will suggest, the switch to a categorical approach may require the Court to answer a question left tantalizingly unresolved by Dunsmuir.

Having had regard in Dunsmuir to the difficulties in applying a tripartite standard of review, the majority of the Court felt compelled to "conclude that the two variants of reasonableness review should be collapsed into a single form of 'reasonableness' review." ${ }^{200}$ The correctness standard was untouched, but a new, unified standard of reasonableness was announced by Justices Bastarache and LeBel. Reasonableness, they explained, is concerned with justification, transparency, and intelligibility within the decision-making process as well as with whether the decision falls within a range of acceptable and rational solutions. ${ }^{201}$ Justice Binnie suggested in his concurring reasons in Dunsmuir that the unified standard of reasonableness might contain degrees of deference within it, given that "different administrative decisions command different degrees of deference, depending on who is deciding what." ${ }^{202}$ Later, speaking for the majority of the Court in Canada (Citizenship and Immigration) $v$ Khosa, ${ }^{203}$ Justice Binnie was less explicit: "Reasonableness is a single standard that takes its colour from the context." 204

The emphasis on the importance of context is sensible as a matter of logic; the unified reasonableness standard in Dunsmuir cannot apply itself. The range of outcomes must be determined by reference to some starting point, as must the concrete content of abstract concepts, such as justification, transparency, and intelligibility. The problem with the Khosa refinement, however, is that it leaves unclear what "context" is. The dangers attendant upon this lack of clarity are exemplified by the judgment of Justice Rouleau in Mills $v$ Ontario (Workplace Safety and Insurance Appeals Tribunal)::205

200. Dunsmuir, supra note 21 at para 45.

201. Ibid at para 47.

202. Ibid at para 135. See also Fraternité des policiers, supra note 100 at paras 13-14; Globalive, supra note 58 at para 32.

203. Supra note 156.

204. Ibid at para 59.

205. 2008 ONCA 436, 168 ACWS (3d) 679. 
Applying the reasonableness standard will now require a contextual approach to deference where factors such as the decision-making process, the type and expertise of the decision-maker, as well as the nature and complexity of the decision will be taken into account. Where, for example, the decision-maker is a minister of the Crown and the decision is one of public policy, the range of decisions that will fall within the ambit of reasonableness is very broad. In contrast, where there is no real dispute on the facts and the tribunal need only determine whether an individual breached a provision of its constituent statute, the range of reasonable outcomes is, perforce, much narrower. ${ }^{206}$

At no point does Justice Rouleau explain from whence springs his reliance on the status of the decision maker, whether the decision is a "public policy" decision or whether there is "no real dispute" on the facts. There may be something to be said for a departure from the four factors relied on in the standard of review analysis, but it ought to be stated explicitly. For now, the risk created by an openended definition of reasonableness that "takes its colour from the context"207 is that a potentially unlimited number of factors might be taken into account by reviewing courts in their determination of context.

It seems to me that there are really only two possible means of preventing the judicial determination of context from sliding into a morass of multiple considerations, the significance of which changes from one case to the next. ${ }^{208}$ One possibility is that the severity of the error complained of defines the context. The more serious the error or errors made by the decision maker, the more work the decision maker will have to do to convince the reviewing court that the decision was, nonetheless, reasonable. To put it another way, the more severe the error, the greater the burden on the decision maker to demonstrate that the decision was within the range of reasonable outcomes and to show the justification, transparency, and intelligibility of the process by which it was taken. Yet this approach was ruled out by the Court in Dunsmuir when it jettisoned the patent unreasonableness standard. In the end, a focus on severity will inevitably prove unavailing. To say that a decision is "clearly irrational" rather than "irrational" is "surely a tautology," ${ }^{09}$ and a statement that an error is 'very severe' rather than

206. Ibid at para 22.

207. Khosa, supra note 156 at para 59.

208. For an extreme example, see Pharmascience Inc v Canada (Attorney General), 2008 FCA 258 at para 4, 68 CPR (4th) 459. See also Catalyst, supra note 58 at paras 17, 21, 24. In Catalyst, the Court apparently announced a reasonableness standard that is unique to review of municipal by-laws, a stance it was seemingly pushed into adopting by a variety of contextual factors.

209. David J Mullan, "Recent Developments in Standard of Review" in Taking the Tribunal to Court: A Practical Guide for Administrative Law Practitioners (Ontario: Canadian Bar Association, 2000) at 25. 
'severe simpliciter' has the same tautological quality. As Justice LeBel argued in an influential set of concurring reasons:

There seems to me to be no qualitative basis on which to differentiate effectively between these various characterizations of a rationality analysis; how, for instance, would a decision that is not "tenably supported" (and is thus "merely" unreasonable) differ from a decision that is not "rationally supported" (and is thus patently unreasonable)? $?^{210}$

Justice Bastarache subsequently made the same point extra-judicially: "Much like being somewhat pregnant, one cannot be somewhat unreasonable." 211 If the context for the purposes of a reasonableness analysis is composed, to any degree, of the severity of the error complained of, it runs into the difficulties identified by Justices Bastarache and LeBel in Dunsmuir. ${ }^{212}$

The second possibility is that context is determined by the factors in the standard of review analysis. ${ }^{213}$ For example, according to David Mullan's interpretation of Justice Binnie, "[U]nder the umbrella of unreasonableness review, questions of fact should be approached with particular care and deference."214 The British Columbia Court of Appeal has suggested that the range of acceptable outcomes will be "dictated by the nature of the question." 215 Expertise, statutory purpose, and the presence or absence of privative or appeal clauses could also contribute to the relevant context, making it more or less deferential. The irony of shooing the standard of review analysis out the front door while allowing it to skulk in through the back door is striking. But this approach suggests that the Court's attempts to marginalize the standard of review analysis are doomed to failure. Something must determine the context for the application of the unified reasonableness standard, and the standard of review analysis (or some variant thereon) seems the most plausible candidate. In the wake of Dunsmuir, the old standard of review factors seem to be capable of exercising an influence-from the intensive care unit, if not from beyond the grave. But if that is the case, the

210. Toronto (City) $v$ Canadian Union of Public Employees (CUPE), Local 79, 2003 SCC 63 at para 107, 3 SCR 77.

211. Bastarache, supra note 132 at 235.

212. Dunsmuir, supra note 21 at paras 40-42.

213. Gerald P Heckman, "Substantive Review in Appellate Courts since Dunsmuir" (2009) 47:4 Osgoode Hall LJ 751 at 778-79.

214. David Mullan, "Proportionality - a Proportionate Response to an Emerging Crisis in Canadian Judicial Review Law?” (2010) NZL Rev 233 at 248. Binnie J was explicit about this in his concurring reasons in Alberta Teachers' Association, supra note 56 at paras 85-89.

215. Teamsters Local Union No 31 v Shadow Lines Transportation Group, 2009 BCCA 130 at para 94, 308 DLR (4th) 90, Ryan JA. 
utility of the categorical approach is further reduced, quite apart from its own inherent flaws and internal contradictions.

\section{CONCLUSION: FORM OR SUBSTANCE?}

I have demonstrated numerous shortcomings of the categorical approach advocated by the Court. The development of these particular categories is misguided, relying on dubious abstract concepts and flawed, hidden assumptions. The categories are unclear. They are both over- and under-inclusive. They conflict with one another. They may not even help the Court to achieve its purported aim of marginalizing the standard of review analysis.

More generally, the categorical approach represents the unfortunate triumph of form over substance. By form, I mean the development of conceptual categories into which decisions must be placed without regard to whether the achievement of the substantive ends intended by the development of the categories are actually furthered by placing a particular decision in a category. By substance, I mean paying attention to the eccentricities of the individual decision and the statutory provisions pursuant to which it was made. ${ }^{216}$ For present purposes, I treat the standard of review analysis as an example of a substantive approach. I do not endorse the standard of review analysis-far from it. I examine the flaws in the standard of review analysis elsewhere, in the course of developing an alternative approach. ${ }^{217}$ But compared to the categorical approach, the standard of review analysis is a superior metric in its substantive and deferential orientation. Only against the frailties of the formalistic, categorical approach championed by the Court can the strengths of a more substantive approach be properly appreciated. My discussion of the approach recently pursued by the Court prompts four general observations. The first three relate to the triumph of form over substance; the last relates to the possible shift from the Court's previously deferential posture.

216. See PS Atiyah \& Robert S Summers, Form and Substance in Anglo-American Law (Oxford: Clarendon Press, 1987) at 2-5. The authors suggest the distinction between form and substance. A substantive reason "may be defined as a moral, economic, political, institutional, or other social consideration" whereas a formal reason "is a legally authoritative reason on which judges and others are empowered or required to base a decision or action, and such a reason usually excludes from consideration, overrides, or at least reduces the weight of, any countervailing substantive reasoning arising at the point of decision or action."

217. Daly, A Theory of Deference, supra note 4. I do not argue explicitly for a substantive as opposed to formal approach. Indeed, I suggest therein that my own approach is neither fish nor fowl, at least in terms of the traditional distinction between form and substance in administrative law. 
First, the standard of review analysis largely respects the traditional view of courts as agents of the legislature, with a duty to give effect to legislative intent (while at the same time ensuring that the legislature had remained within its constitutional boundaries). This is not legislative intent in any literal or formalistic sense, but in the sense once described by Lord Reid: Courts should seek "the meaning of the words which Parliament used." ${ }^{218}$ To prefer a categorical approach is to subjugate legislative intent to autonomous judicial development of categories of review. There is precedent for this approach since it is how judicial review has traditionally developed in the Commonwealth. But one of the great advances made by Canadian courts in developing the standard of review analysis was to take legislative enactments seriously. No longer was "legislative intent" treated as a purely formalistic incantation, an empty vessel into which courts could pour their desired judicial review doctrine. Rather, it was treated as providing guidance to courts as to how best to shape the law of judicial review.

Second, the standard of review analysis is substantive and contextual in nature. Its application has forced reviewing courts to confront the nature of the statutory scheme, the nature of the relationship between the particular decision and the relative expertise of the decision maker, and the nature of the particular question presented for review. Perhaps it was too much to expect reviewing courts to abide by this framework. Too long a sacrifice may, after all, make a stone of the heart. From the perspective of an overworked judge struggling to clear a docket, the categorical approach has an appeal that the standard of review analysis cannot hope to match. But as I have demonstrated, that appeal is superficial. The categorical approach cannot hope to capture the nuances of the relationship between reviewing court, legislature, and decision maker. If reviewing courts want to be serious about giving effect to legislative intent, or, at the very least, according due weight to legislative enactments, there is no substitute for grappling with the relevant statutory provisions.

Third, the standard of review analysis had a justificatory value. A reviewing court grappling with the standard of review had to explain its choice of standard. Perhaps it was too much to hope for a fully transparent explanation in all cases, but the standard of review analysis at least pushed reviewing courts in the direction of clear public pronouncements. By contrast, the categorical approach makes it too easy for reviewing courts simply to pick a category into which a decision falls with scant explanation as to why it does so. Viewed from the perspective of one who values transparency in judicial decision making, the (apparent) demise of the standard of review analysis is to be lamented.

218. Black-Clawson International Ltd v Papierwerke Waldhof-Aschaffenburg AG, [1975] AC 591 at 613, 2 WLR 513 (HL). 
Fourth, requiring reviewing courts to perform a standard of review analysis in all cases gave effect to a general policy of judicial deference. A reviewing court bent on applying a standard of review of correctness would have to jump through all the hoops of the standard of review analysis before doing so. Indeed, this exercise might have prompted many a reviewing court to reconsider its initial preference for a correctness standard. Now, however, the advent of the categorical approach makes it much easier for a reviewing court to avoid being deferential. As I have demonstrated, categorization will often be contestable, but the courts have identified no criteria to guide the choice between the categories. A reviewing court minded to apply a correctness standard can simply choose one of the categories to which a standard of review of correctness applies. The barriers between a decision maker and a non-deferential court erected by the standard of review analysis have been torn down by Dunsmuir and the Court's subsequent decisions.

Nonetheless, there are encouraging signs. The Court has recently leaned towards review on a standard of reasonableness on the contentious questions that have come before it. ${ }^{219}$ Moreover, in Newfoundland and Labrador Nurses' Union v Newfoundland and Labrador (Treasury Board), ${ }^{220}$ the Court made clear that concern about the erosion of deference motivated it to treat the adequacy of reasons as going to the reasonableness or unreasonableness of a decision, rather than to procedural fairness. Alleged shortcomings in the adequacy of reasons are not to be reviewed on a standard of correctness. ${ }^{221}$ In light of this decision, and that of the majority of the Court in Alberta Teachers' Association, one lower court judge has suggested that, in effect, "the Supreme Court has told reviewing Courts to 'back off, at least in reviewing an administrative body's interpretation of its home statute, closely related statutes, and frequently encountered common law principle."222 Moving back in the direction of a substantive approach to judicial review would cohere with these apparent tendencies towards deference. The Court ought to do so.

219. See text accompanying supra notes 177-193.

220. 2011 SCC 62, 3 SCR 708.

221. Ibid at para 21.

222. Procrane Inc (Sterling Crane) v Alberta (Appeals Commission for Alberta Workers' Compensation), 2012 ABQB 37 at para 22, AJ No 55 (QL), Clackson J. 